\title{
Lipoglycopeptide Antibacterial Agents in Gram-Positive Infections: A Comparative Review
}

\author{
Françoise Van Bambeke ${ }^{1}$ (I)
}

Published online: 24 November 2015

(C) Springer International Publishing Switzerland 2015

\begin{abstract}
Oritavancin, telavancin, and dalbavancin are recently marketed lipoglycopeptides that exhibit remarkable differences to conventional molecules. While dalbavancin inhibits the late stages of peptidoglycan synthesis by mainly impairing transglycosylase activity, oritavancin and telavancin anchor in the bacterial membrane by the lipophilic side chain linked to their disaccharidic moiety, disrupting membrane integrity and causing bacteriolysis. Oritavancin keeps activity against vancomycin-resistant enterocococci, being a stronger inhibitor of transpeptidase than of transglycosylase activity. These molecules have potent activity against Grampositive organisms, most notably staphylococci (including methicillin-resistant Staphylococcus aureus and to some extent vancomycin-intermediate S. aureus), streptococci (including multidrug-resistant pneumococci), and Clostridia. All agents are indicated for the treatment of acute bacterial skin and skin structure infections, and telavancin, for hospitalacquired and ventilator-associated bacterial pneumonia. While telavancin is administered daily at $10 \mathrm{mg} / \mathrm{kg}$, the remarkably long half-lives of oritavancin and dalbavancin allow for infrequent dosing (single dose of $1200 \mathrm{mg}$ for oritavancin and $1000 \mathrm{mg}$ at day 1 followed by $500 \mathrm{mg}$ at day 8 for dalbavancin), which could be exploited in the future for outpatient therapy. Among possible safety issues evidenced during clinical development were an increased risk of developing osteomyelitis with oritavancin; taste disturbance, nephrotoxicity, and risk of corrected QT interval prolongation (especially in the presence of at-risk co-medications) with
\end{abstract}

Françoise Van Bambeke

francoise.vanbambeke@uclouvain.be

1 Pharmacologie cellulaire et moléculaire, Louvain Drug Research Institute, Université catholique de Louvain, Avenue Mounier 73 B1.73.05, 1200 Brussels, Belgium telavancin; and elevation of hepatic enzymes with dalbavancin. Interference with coagulation tests has been reported with oritavancin and telavancin. These drugs proved non-inferior to conventional treatments in clinical trials but their advantages may be better evidenced upon future evaluation in more severe infections.

\section{Key Points}

New lipoglycopeptides (telavancin, oritavancin, dalbavancin) differ from vancomycin by the presence of a lipophilic side chain, which profoundly modifies their pharmacokinetic and/or pharmacodynamic profile.

Among these agents, telavancin and oritavancin have multiple modes of action and are highly bactericidal.

Oritavancin and dalbavancin have prolonged halflives, allowing for their use a single-dose or twodose (once-a-week) regimen, respectively.

These three drugs are indicated for the treatment of acute bacterial skin and skin structure infections, and telavancin is indicated for hospital-acquired and ventilator-associated bacterial pneumonia.

\section{Introduction}

Glycopeptide antibacterials (vancomycin, teicoplanin) were introduced on the market as early as the 1950s and 1980s, respectively. Over the last 6 years, three new drugs have been registered and commercialized (see 
vancomycin
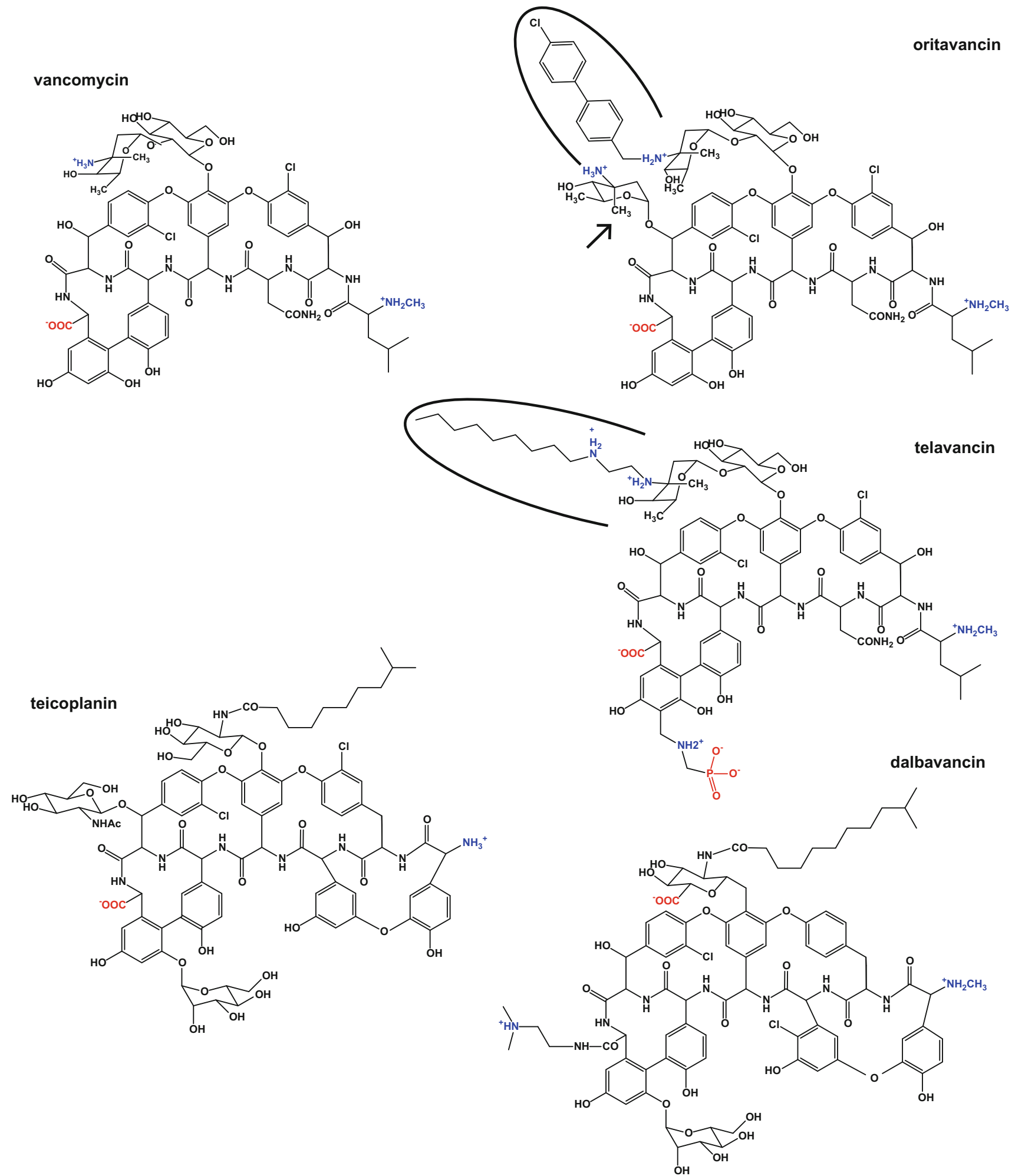

telavancin

Fig. 1 Chemical structure of new glycopeptides as compared to conventional molecules. Substituents that are positively charged at physiological $\mathrm{pH}$ are highlighted in blue and those that are negatively charged are highlighted in red. The $\alpha$-carbon atom of each residue is numbered in vancomycin. Lipophilic side chains conferring bactericidal character to oritavancin and telavancin are marked by black arcs. The additional sugar allowing for cooperative binding in oritavancin is pointed to by a black arrow 
Fig. 1 for their chemical structures) and are referred to as lipoglycopeptides because they possess an additional lipophilic side chain compared with vancomycin. Among them, telavancin and oritavancin are very innovative, as they show an additional mode of action and a rapidly bactericidal character due to the presence of this lipophilic side chain attached to the disaccharide moiety. On the other hand, dalbavancin, the lipophilic side chain of which is located on the same position as that found in teicoplanin, shows an improved pharmacokinetic profile but the same mode of action as teicoplanin. This review compares the microbiological and pharmacological properties, clinical use, and potential usefulness of these three molecules with those of vancomycin. A PubMed search was performed using the keywords oritavancin (or LY333328), telavancin (or TD-6424), dalbavancin (or BI397). All papers published over the last 5 years were examined. Older papers were also considered if dealing with discovery, pharmacokinetics, pharmacodynamics, mode of action, clinical trials, or toxicity.

\section{Discovery and History}

\subsection{Oritavancin}

Oritavancin is a semi-synthetic derivative of the naturally occurring lipoglycopeptide chloroeremomycin. Chloroeremomycin differs from vancomycin by the presence of an additional aminated sugar (4-epi-vancosamine) on the amino acid 6 of the cyclic heptapeptide and the replacement of the 4-vancosamine by a 4-epi-vancosamine in the disaccharide attached to the aglycone moiety [1]. In oritavancin, the addition of a chlorobiphenylmethyl side chain to this disaccharide is responsible for the amphipathic character of the molecule.

Oritavancin was discovered at Eli Lilly [1] as LY333328 (see Allen [2] for a full history of this molecule). It was selected as a candidate for clinical development in 1994 based on its excellent activity in vitro and in vivo as well as on a favorable pharmacokinetic profile. After Eli Lilly decided to terminate its activities in the field of anti-infective drugs, oritavancin was transferred to InterMune (San Francisco, CA, USA) in 2002, where additional phase I trials were conducted. InterMune also decided to re-focus its activities and sold the molecule to Targanta Therapeutics (Montreal, QC, Canada) in 2006. Many additional in vitro investigations were performed at that time that better documented the mechanism of action of the drug as well as its activity in specific models of infection. Data from additional phase I and II trials suggest that infrequent dosing could be used and effective $[3,4]$.
In 2008, Targanta submitted new drug applications to the US Food and Drug Administration (FDA) and European Medicines Agency (EMA), with a dosing scheme of $1.5-3 \mathrm{mg} / \mathrm{kg} /$ day for 3-7 days [5]. These applications were not accepted because of insufficient clinical evidence of efficacy and safety. The Medicines Company (Parsippany, NJ, USA) acquired oritavancin in 2009, completed additional pharmacological investigations, and ran phase III trials with an innovative therapeutic scheme that eventually led to the registration of the drug for the treatment of complicated skin and skin structure infections by both the American and European Agencies in 2014 [6, 7].

\subsection{Telavancin}

Telavancin is a semi-synthetic derivative of vancomycin, in which a hydrophobic (decylaminoethyl) side chain is added to the disaccharide. A phosphonomethylaminomethyl substituent on the cyclic peptidic core counterbalances to some extent the hydrophobicity brought by this lipophilic side chain. The molecule was named TD6424 by Theravance [now Theravance BioPharma (San Francisco, CA, USA)] [8]. Remarkably, this small company was able to conduct the preclinical and clinical development of the molecule internally in a streamlined fashion (through strategic collaborations with pharmaceutical companies including Astellas Pharma Inc.) and obtained marketing authorization by the FDA in 2009 for the treatment of complicated skin and skin structure infections and by the EMA in 2011 for the treatment of hospital-acquired pneumonia (see Wenzler and Rodvold [9] for a recent review on the discovery and history of the development of this compound). Telavancin was the first marketed product for this company. In situations where other alternatives are not suitable, the accepted indications in the USA now include both complicated skin and skin structure infections and hospital-acquired and ventilatorassociated bacterial pneumonia (HABP/VABP) caused by susceptible isolates of Staphylococcus aureus [10], and in Europe include nosocomial pneumonia, including ventilator-associated pneumonia that is known or suspected to be caused by methicillin-resistant S. aureus (MRSA) [11].

\subsection{Dalbavancin}

Dalbavancin (BI397) is a semi-synthetic derivative from the natural glycopeptide A40926. A40926 differs from teicoplanin by the absence of the acetylglucosamine in the benzylic position, the replacement of the acylglucosamine in position 4 by an acylaminoglucuronic acid, the length of the fatty acid chain, the position of one chlorine atom, and the terminal methylamino group [12]. In dalbavancin, the peptide carboxy group of A40926 has been replaced by a 
3,3-dimethylaminopropylamide [13]. Dalbavancin was discovered by Biosearch and out-licensed for North America to Versicor. Both companies then merged to create Vicuron Pharmaceuticals (King of Prussia, PA, USA) and continued to develop the product. Vicuron was acquired by Pfizer in 2005, which pursued the development of dalbavancin to the point where the FDA requested additional clinical data before approval. In 2009, the drug was then acquired by Durata Therapeutics (Chicago, IL, USA), which initiated new phase III trials. The drug was approved by the FDA in 2014 and by the EMA in 2015 for the treatment of complicated skin and skin structure infections $[14,15]$. Durata Therapeutics was acquired by Actavis (Parsippany, NJ, USA) in 2014, which commercializes dalbavancin today (see Butler et al. [16] for a review of this history).

\section{Activity}

\subsection{Mechanism of Action and of Resistance for Conventional Glycopeptides}

Conventional glycopeptides inhibit the late stages of peptidoglycan synthesis (Fig. 2). Via their aglycone moiety, they establish five hydrogen bounds with the D-Ala-D-Ala termini of pentapeptidic precursors, which by steric hindrance prevents the transglycosylation reaction leading to the extension of the glycan backbone of peptidoglycan as well as the transpeptidation reaction leading to the crosslinking of pentapeptide bridges [17, 18]. This mode of action confers a slowly bactericidal character to vancomycin, which is limited to fast-growing organisms [19]. Resistance to vancomycin has emerged over the years and is mediated by two distinct mechanisms. In S. aureus, a thickening of the cell wall confers a so-called VISA (vancomycin-intermediate $S$. aureus) phenotype, with the minimum inhibitory concentration (MIC) typically ranging between 3 and $8 \mathrm{mg} / \mathrm{L}$. This phenotype was first described in 1997 [20]. The underlying mechanism is not yet fully elucidated but it has been associated with mutations in the RNA polymerase gene $r p o B$ and in genes that are directly or indirectly involved in the biosynthesis/metabolism of the cell wall, including two-component sensory regulatory systems (for a recent review, see Gardete and Tomasz [21]). In enterococci, high-level resistance is mediated by the occurrence of an alternative pathway for cell wall synthesis. It results from the acquisition of transposon-encoding genes that allow for (a) the hydrolysis of precursors ending in D-Ala-D-Ala and (b) the synthesis of cell wall precursors ending in D-Ala-D-Lac or D-Ala-D-Ser and showing reduced affinity for glycopeptides (see Courvalin [22] for a review). Very few cases of $S$. aureus that have acquired this type of transposon and harbor high-level resistance to vancomycin [vancomycin-resistant $S$. aureus (VRSA)] have been described but they do not seem to spread so far [23].

\subsection{Mechanism of Action of Lipoglycopeptides}

Because all lipoglycopeptides keep the aglycone moiety of conventional molecules in their structure, they also conserve this primary mode of action. Yet their specific chemical features confer to them additional antibacterial properties. An early work [24] suggested that the interaction between glycopeptides and the D-Ala-D-Ala motif can be enhanced by two mechanisms, namely (a) the formation of homodimers between glycopeptide molecules, which confers a structural rigidity that locks the binding pocket into the correct conformation and may allow for a cooperative binding to the ligand, and (b) the anchoring of the antibacterial in the membrane, which may help to maintain the drug close to its target (see Van Bambeke et al. [25] for a review).

Dimer formation has been shown to occur with oritavancin $[1,26]$ via the additional 4-epi-vancosamine sugar, putting the molecule in a back-to-back orientation and allowing cooperative binding to the ligand. Dalbavancin also strongly dimerizes in solution, and even in the absence of a ligand [27, 28], but via lipophilic side chains. However, in this case, both dimer formation and interaction with cell wall precursors are non-cooperative (the molecule adopting a 'closed' conformation upon ligand binding) and do not contribute to improve the antibacterial activity.

Membrane anchoring has been documented for both oritavancin and telavancin via their lipophilic side chain linked to the disaccharide moiety $[29,30]$. Both molecules also cause aberrant septum formation and loss of staining of nascent septal cross walls in electron microscopy, which may result from their effect on cell wall synthesis and/or activation of autolysins [31]. Yet oritavancin shows the unique property of keeping activity against vancomycinresistant enterococci (VRE) and staphylococci [32].

For telavancin, a specific, high-affinity interaction with lipid II has been demonstrated, leading to membrane depolarization, bacterial lysis, and rapid bactericidal effect $[30,33]$. Microarray analyses revealed that after $15 \mathrm{~min}$ of exposure to the drug a strong expression of the cell wall stress stimulon (characteristic response to inhibition of cell wall biosynthesis), which was accompanied after $60 \mathrm{~min}$ of exposure by an induction of various genes, was also affected by other membrane-depolarizing drugs [34]. These data support a dual mode of action and may explain the bimodal shape of concentration-effect relationships in killcurve experiments [35]. 


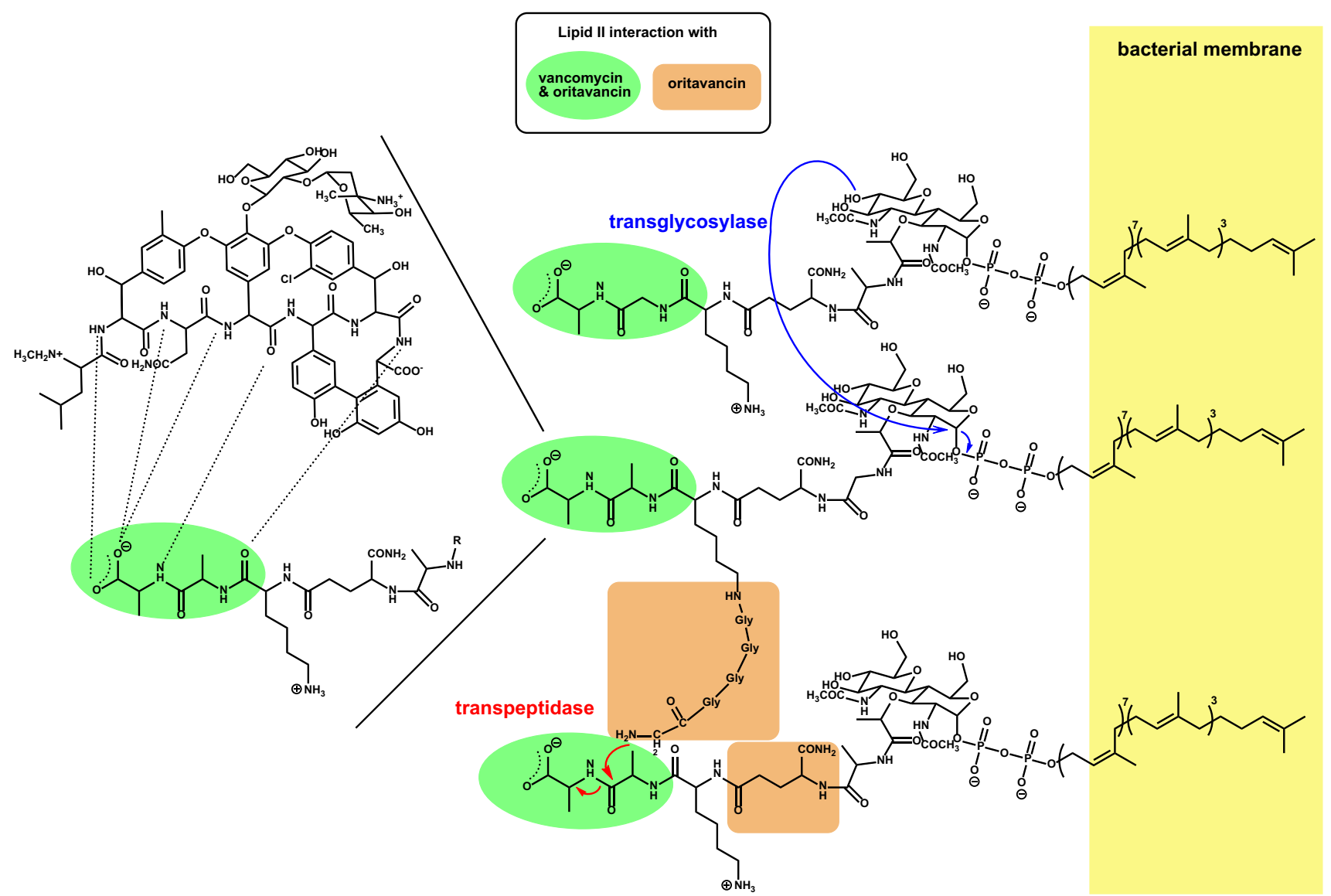

Fig. 2 Illustration of the late stages of peptidoglycan synthesis [transglycosylation (in blue) and transpeptidation (in red) reactions] and of the way vancomycin and oritavancin interact with the lipid II precursor in order to inhibit these reactions. Vancomycin and new lipoglycopeptides establish 5 hydrogen bounds with the D-Alanyl-DAlanine extremity of the pentapeptidic terminus of lipid II (zone highlighted in green) [17], which leads, by steric hindrance, to an inhibition of the glycan chain extension and, to a lesser extent, of crosslinking between peptidic stems. Oritavancin has additional interactions with the pentaglycyl bridge and the D-iso-glutamine residue in position 2 of the pentapeptide terminus of lipid II (zone highlighted in orange) [37], which allow it to be a stronger inhibitor of transpeptidases [38]
Oritavancin also disrupts membrane integrity and causes membrane depolarization both in bacterial cells and liposomes reconstituted from lipids of S. aureus [29, 36]. These effects are also related to the capacity of oritavancin to specifically bind to lipid II, with additional interaction sites compared with its precursor chloreremomycin, which can explain its improved activity on vancomycin-resistant strains [37]. Solid-state nuclear magnetic resonance (NMR) studies have indeed shown that oritavancin possesses two binding sites on the lipid-linked disaccharide-pentapeptide monomers in S. aureus (D-Ala-D-Ala termini, like vancomycin, but also the pentaglycyl bridging segment via its lipophilic side chain on the dissacharide and components of its aglycon structure). This allows it to inhibit not only transglycosylase activity, and thus precursor chain extension, but also transpeptidase activity, and thus precursor cross-linking [38]. In Enterococcus faecium, inhibition of transpeptidase becomes even more prominent due to the preferential interaction of oritavancin with multiple sites on the peptidic bridge [39]. In this case, interaction with DAla-D-ala termini becomes marginal, explaining why transglycosylase activity is no longer the primary target of the drug. More importantly, this also rationalizes why oritavancin still exerts activity on vancomycin-resistant strains.

\subsection{Spectrum of Activity}

Because of their high molecular weight, lipoglycopeptides, like glycopeptides, cannot cross bacterial membranes and the cell wall, meaning that their spectrum of activity is limited to Gram-positive bacteria in which their target is directly accessible. A large number of studies have examined the in vitro activity of these compounds against 
collections of Gram-positive clinical isolates, yet many of these studies were performed using broth that was not supplemented by polysorbate- 80 , which is needed to prevent the adsorption of the drugs to the plastic [40-42]. Table 1 therefore focuses on recent studies that have used the standard procedure currently recommended by the Clinical Laboratory Standards Institute (CLSI), i.e., $0.002 \%$ polysorbate-80 added to the culture medium [43]. Against vancomycin-susceptible staphylococci, streptococci, or enterococci, the three drugs show quite similar MIC distributions and are more potent than vancomycin. Yet a clear-cut correlation between the MICs of vancomycin and of the lipoglycopeptides has been demonstrated, and thus vancomycin MIC can be used as a surrogate for susceptibility to lipoglycopeptides [44-46]. Oritavancin is slightly more potent than the other compounds on enterococci. It is also the only one to keep useful activity against VRE harboring the vanA genotype or against VRSA [47]. Teicoplanin, dalbavancin, and telavancin remain active on $v a n B$-type resistant strains because they are not inducers for this specific resistance genotype [48, 49]. The MICs are 2-4 dilutions higher against VISA than against MRSA for the three drugs [47, 50, 51].

Like vancomycin, lipoglycopeptides are active on Clostridia, including $C$. difficile, with MICs measured in the absence of polysorbate ranging from 0.125 to $2 \mathrm{mg} / \mathrm{L}$ for oritavancin [52] (1 dilution lower with polysorbate-80 [53]), 0.25 to $0.5 \mathrm{mg} / \mathrm{L}$ for telavancin [54], and 0.125 to $0.5 \mathrm{mg} / \mathrm{L}$ for dalbavancin [55]. In addition, oritavancin proved effective against $C$. difficile infection after 4 days of treatment in an in vitro model of human gut [56] and does not induce spore germination or toxin production both in vitro and in vivo [57, 58].

Resistance to lipoglycopeptides has not yet been described in clinics; it is less likely to occur for drugs showing multiple modes of action. In laboratory mutants, a moderate level of resistance to oritavancin in enterococci has been ascribed to the complete elimination of precursors ending in D-Ala-D-Ala during cell wall synthesis, or to the expression of the accessory gene vanZ, which also confers resistance to teicoplanin by an unknown mechanism [59]. Mutations in the sensor $\mathrm{VanS}_{\mathrm{B}}$ of Enterococcus faecalis can also induce low-level resistance to both teicoplanin and oritavancin, which are not inducers of the wild-type $\operatorname{VanS}_{\mathrm{B}}$ sensor. Transcriptomic studies of a telavancin-resistant mutant in $S$. aureus revealed multiple changes in gene expression, including upregulation of genes involved in cell wall or fatty acid biosynthesis as well as stress response, and downregulation of genes included in lysine biosynthesis, synthesis of surface proteins, modulin or proteases, and anaerobic metabolism as well as global regulators such as agr [60]. These changes are accompanied by a thickening of the cell wall and a decrease in the activity of autolysins, which is reminiscent of what is observed in VISA strains.

\subsection{In Vitro Models of Persistent Infections}

Staphylococci, which constitute the primary therapeutic target for these drugs, may adopt specific lifestyles associated with the persistent or recurrent character of infection, namely growth within biofilm [61] and intracellular survival [62]. The activity of lipoglycopeptides on these specific types of infections has thus been investigated in appropriate models.

Against static biofilms grown on plastic pegs and made of methicillin-sensitive $S$. aureus (MSSA), MRSA or VISA, oritavancin was effective at minimal biofilm eradication concentrations (MBECs) ranging between 0.5 and $8 \mathrm{mg} / \mathrm{L}$, which are only 1 dilution higher than the MICs [63]. Telavancin activity has been investigated in a wide range of biofilm models, including in vitro static and dynamic models with MSSA, MRSA, VISA, or even enterococci [64-66] as well as animal models (see Chan et al. [67] for an indepth review on this specific topic). Globally speaking, telavancin proves as, or often more, effective than vancomycin thanks to its bactericidal character.

Against intracellular bacteria infecting THP-1 cells (native monocytes or differentiated in macrophages), oritavancin appears to be the most effective of all the antibacterials tested in this model, reaching a true intracellular bactericidal effect $\left(-3 \log _{10}\right.$ decrease in bacterial counts), as demonstrated against intracellular MSSA [68, 69], MRSA, VISA (including strains collected from a patient with bacteremia) [70], or even small colony variants [71-73]. It also proved synergistic with other bactericidal antibacterials such as fluoroquinolones or rifampicin against small colony variants [74]. This remarkable intracellular activity was attributed to the capacity of oritavancin to accumulate within the lysosomes of cells to exceptionally high levels by a process of adsorptive endocytosis [75]. Telavancin was also more effective than vancomycin in THP-1 cells infected by MSSA, MRSA, or VISA, reaching a bactericidal effect after $3 \mathrm{~h}$; however, its activity was much slower against VRSA, with a bactericidal effect being reached only after $24 \mathrm{~h}$ of incubation with concentrations higher than ten times the MIC [35].

Nevertheless, the high accumulation of oritavancin inside eukaryotic cells raises the question of a potential toxicity. In vitro studies have indeed demonstrated the deposition of undigested lipidic material within lysosomes of cells exposed to the drug continuously for 1-3 days [76], but only in conditions generating intracellular concentrations well above those measured in macrophages from patients treated with the drug [77]. Moreover, this effect was reversible upon drug removal [76]. When the exposure 
Table 1 Minimum inhibitory concentration distributions of new lipoglycopeptides versus vancomycin against clinically relevant pathogens ${ }^{\mathrm{a}}$

\begin{tabular}{|c|c|c|c|c|c|c|c|c|c|c|}
\hline \multirow[t]{2}{*}{ Bacterial species } & \multirow[t]{2}{*}{ Phenotype } & \multirow{2}{*}{$\begin{array}{l}\text { Number } \\
\text { of strains }\end{array}$} & \multicolumn{4}{|c|}{ New glycopeptides } & \multicolumn{3}{|c|}{ Vancomycin } & \multirow[t]{2}{*}{ References } \\
\hline & & & Antibacterial & $\begin{array}{l}\text { Range } \\
(\mathrm{mg} / \mathrm{L})\end{array}$ & $\begin{array}{l}\mathrm{MIC}_{50} \\
(\mathrm{mg} / \mathrm{L})\end{array}$ & $\begin{array}{l}\mathrm{MIC}_{90} \\
(\mathrm{mg} / \mathrm{L})\end{array}$ & $\begin{array}{l}\text { Range } \\
(\mathrm{mg} / \mathrm{L})\end{array}$ & $\begin{array}{l}\mathrm{MIC}_{50} \\
(\mathrm{mg} / \mathrm{L})\end{array}$ & $\begin{array}{l}\mathrm{MIC}_{90} \\
(\mathrm{mg} / \mathrm{L})\end{array}$ & \\
\hline \multirow{4}{*}{$\begin{array}{l}\text { MSSA (methicillin- } \\
\text { susceptible } \\
\text { Staphylococcus aureus) }\end{array}$} & All & 3245 & TLV & $\begin{array}{l}\leq 0.015 \\
\text { to } 0.12\end{array}$ & 0.03 & 0.06 & & & & {$[40]$} \\
\hline & All & 1460 & ORI & $\begin{array}{l}\leq 0.004 \\
\text { to } 0.25\end{array}$ & 0.03 & 0.06 & $\begin{array}{c}\leq 0.12 \\
\text { to } 2\end{array}$ & 0.5 & 1 & {$[50]$} \\
\hline & All & 2958 & ORI & $\begin{array}{l}\leq 0.008 \\
\text { to } 0.25\end{array}$ & 0.03 & 0.06 & $\begin{array}{c}\leq 0.12 \\
\text { to } 2\end{array}$ & 1 & 1 & {$[173]$} \\
\hline & All & 514 & DAL & $\begin{array}{l}\leq 0.03 \text { to } \\
0.25\end{array}$ & 0.06 & 0.06 & $\begin{array}{c}\leq 0.12 \\
\text { to } 2\end{array}$ & 1 & 1 & [174] \\
\hline \multirow[t]{7}{*}{$\begin{array}{l}\text { MRSA (methicillin-resistant } \\
\text { S. aureus) }\end{array}$} & All & 3019 & TLV & $\begin{array}{l}\leq 0.015 \\
\text { to } 0.25\end{array}$ & 0.03 & 0.06 & $\begin{array}{c}0.25 \text { to } \\
4\end{array}$ & 1 & 1 & {$[40]$} \\
\hline & All & 427 & ORI & $\begin{array}{l}\leq 0.004 \\
\text { to } 0.25\end{array}$ & 0.03 & 0.06 & $\begin{array}{c}0.5 \text { to } \\
2\end{array}$ & 1 & 1 & {$[50]$} \\
\hline & All & 3376 & ORI & $\begin{array}{l}\leq 0.008 \\
\text { to } 0.25\end{array}$ & 0.03 & 0.06 & $\begin{array}{l}0.25 \text { to } \\
2\end{array}$ & 1 & 1 & [173] \\
\hline & All & 522 & DAL & $\begin{array}{l}\leq 0.03 \text { to } \\
0.12\end{array}$ & 0.06 & 0.06 & $\begin{array}{c}0.5 \text { to } \\
2\end{array}$ & 1 & 1 & [174] \\
\hline & All & 61,195 & DAL & $\begin{array}{l}\leq 0.008 \\
\text { to } 0.25\end{array}$ & 0.06 & 0.06 & $\begin{array}{r}\leq 0.12 \\
\text { to } 4\end{array}$ & 1 & 1 & {$[175]$} \\
\hline & $\begin{array}{l}\text { VAN } \\
\quad \text { MIC } \geq 2\end{array}$ & 115 & TLV & $\begin{array}{l}\leq 0.015 \\
\text { to } 0.12\end{array}$ & 0.06 & 0.06 & & & & {$[40]$} \\
\hline & $\begin{array}{l}\text { VAN } \\
\quad \text { MIC } \geq 2\end{array}$ & 124 & ORI & $\begin{array}{l}0.015 \text { to } \\
0.25\end{array}$ & 0.06 & 0.06 & & & & {$[173]$} \\
\hline Staphylococcus epidermidis & All & 221 & ORI & $\begin{array}{l}0.008 \text { to } \\
0.5\end{array}$ & 0.06 & 0.12 & $\begin{array}{c}\leq 0.12 \\
\text { to } 2\end{array}$ & 1 & 2 & {$[50]$} \\
\hline \multirow[t]{2}{*}{$\begin{array}{l}\text { Coagulase-negative } \\
\text { staphylococci (CONS) }\end{array}$} & All & 461 & TLV & $\begin{array}{l}\leq 0.015 \\
\text { to } 0.12\end{array}$ & 0.06 & 0.06 & $\begin{array}{c}0.5 \text { to } \\
4\end{array}$ & 1 & 2 & [40] \\
\hline & All & 115 & DAL & $\begin{array}{l}\leq 0.03 \text { to } \\
0.25\end{array}$ & $\leq 0.03$ & 0.06 & $\begin{array}{l}0.25 \text { to } \\
2\end{array}$ & 1 & 2 & {$[174]$} \\
\hline \multirow[t]{5}{*}{ Enterococcus faecalis } & All & 304 & ORI & $\begin{array}{r}\leq 0.004 \\
\text { to } 0.5\end{array}$ & 0.03 & 0.06 & $\begin{array}{c}0.25 \text { to } \\
4\end{array}$ & 1 & 2 & {$[50]$} \\
\hline & VAN-S & 325 & TLV & $\begin{array}{l}\leq 0.015 \\
\text { to } 0.25\end{array}$ & 0.12 & 0.12 & $\begin{array}{c}0.5 \text { to } \\
4\end{array}$ & 1 & 1 & [40] \\
\hline & VAN-S & 1320 & ORI & $\begin{array}{l}\leq 0.008 \\
\text { to } 0.25\end{array}$ & 0.015 & 0.03 & $\begin{array}{l}0.25 \text { to } \\
4\end{array}$ & 1 & 2 & {$[173]$} \\
\hline & VanA & 45 & ORI & $0.03-1$ & 0.25 & 0.5 & $>16$ & $>16$ & $>16$ & {$[173]$} \\
\hline & VanB & 19 & ORI & $\begin{array}{l}\leq 0.008 \\
\text { to } 0.06\end{array}$ & 0.015 & 0.03 & $\begin{array}{l}8 \text { to } \\
>16\end{array}$ & $>16$ & $>16$ & {$[173]$} \\
\hline \multirow[t]{7}{*}{ Enterococcus faecium } & VAN-S & 81 & TLV & $\begin{array}{l}\leq 0.015 \\
\text { to } 0.12\end{array}$ & 0.03 & 0.06 & $\begin{array}{l}0.25 \text { to } \\
4\end{array}$ & 1 & 1 & [40] \\
\hline & VAN-S & 87 & ORI & $\begin{array}{l}\leq 0.004 \\
\text { to } 0.03\end{array}$ & 0.008 & 0.015 & $\begin{array}{l}0.25 \text { to } \\
2\end{array}$ & 0.5 & 1 & {$[50]$} \\
\hline & VAN-S & 177 & ORI & $\begin{array}{l}\leq 0.008 \\
\text { to } 0.03\end{array}$ & $\leq 0.008$ & $\leq 0.008$ & $\begin{array}{c}0.25 \text { to } \\
4\end{array}$ & 1 & 1 & [173] \\
\hline & VanA & 241 & TLV & $\begin{array}{r}\leq 0.015 \\
\text { to }>2\end{array}$ & 1 & 2 & $>16$ & $>16$ & $>16$ & [40] \\
\hline & VanA & 22 & ORI & $\begin{array}{r}\leq 0.004 \\
\text { to } 0.5\end{array}$ & 0.008 & 0.12 & $\begin{array}{l}32 \text { to } \\
>32\end{array}$ & $>32$ & $>32$ & {$[50]$} \\
\hline & VanA & 600 & ORI & $\begin{array}{r}\leq 0.008 \\
\text { to } 0.5\end{array}$ & 0.03 & 0.12 & $>16$ & $>16$ & $>16$ & [173] \\
\hline & VanB & 16 & ORI & $\begin{array}{l}\leq 0.008 \\
\text { to } 0.03\end{array}$ & $\leq 0.008$ & $\leq 0.008$ & $\begin{array}{l}8 \text { to } \\
>16\end{array}$ & $>16$ & $>16$ & [173] \\
\hline
\end{tabular}


Table 1 continued

\begin{tabular}{|c|c|c|c|c|c|c|c|c|c|c|}
\hline \multirow[t]{2}{*}{ Bacterial species } & \multirow[t]{2}{*}{ Phenotype } & \multirow{2}{*}{$\begin{array}{l}\text { Number } \\
\text { of strains }\end{array}$} & \multicolumn{4}{|c|}{ New glycopeptides } & \multicolumn{3}{|c|}{ Vancomycin } & \multirow[t]{2}{*}{ References } \\
\hline & & & Antibacterial & $\begin{array}{l}\text { Range } \\
(\mathrm{mg} / \mathrm{L})\end{array}$ & $\begin{array}{l}\mathrm{MIC}_{50} \\
(\mathrm{mg} / \mathrm{L})\end{array}$ & $\begin{array}{l}\mathrm{MIC}_{90} \\
(\mathrm{mg} / \mathrm{L})\end{array}$ & $\begin{array}{l}\text { Range } \\
(\mathrm{mg} / \mathrm{L})\end{array}$ & $\begin{array}{l}\mathrm{MIC}_{50} \\
(\mathrm{mg} / \mathrm{L})\end{array}$ & $\begin{array}{l}\mathrm{MIC}_{90} \\
(\mathrm{mg} / \mathrm{L})\end{array}$ & \\
\hline \multirow[t]{3}{*}{ Enterococcus spp. } & VAN-S & 30 & DAL & $\begin{array}{l}\leq 0.03 \text { to } \\
0.12\end{array}$ & $\leq 0.03$ & 0.06 & $\begin{array}{c}0.5 \text { to } \\
2\end{array}$ & 1 & 1 & [174] \\
\hline & VanA & 24 & DAL & $\begin{array}{l}0.24 \text { to } \\
>4\end{array}$ & 4 & 4 & $>16$ & $>16$ & $>16$ & [174] \\
\hline & VanB & 2 & DAL & $\leq 0.03$ & $\leq 0.03$ & & $>16$ & $>16$ & & [174] \\
\hline \multirow[t]{3}{*}{ Streptococcus pneumoniae } & All & 1801 & TLV & $\begin{array}{l}\leq 0.015 \\
\text { to } 0.06\end{array}$ & $\leq 0.015$ & $\leq 0.015$ & $\begin{array}{c}\leq 0.12 \\
\text { to } 2\end{array}$ & 1 & 1 & {$[40]$} \\
\hline & Peni-S & 216 & ORI & $\begin{array}{l}\leq 0.008 \\
\text { to } 0.12\end{array}$ & $\leq 0.008$ & 0.03 & & & & [173] \\
\hline & Peni-R & 86 & ORI & $\begin{array}{l}\leq 0.008 \\
\text { to } 0.25\end{array}$ & 0.015 & 0.06 & & & & [173] \\
\hline \multirow[t]{4}{*}{$\begin{array}{l}\text { Viridans group streptococci } \\
\text { (VGS) }\end{array}$} & All & 446 & TLV & $\begin{array}{l}\leq 0.015 \\
\text { to } 0.06\end{array}$ & $\leq 0.015$ & $\leq 0.015$ & $\begin{array}{c}\leq 0.12 \\
\text { to } 1\end{array}$ & 0.5 & 1 & {$[40]$} \\
\hline & All & 40 & DAL & $\begin{array}{l}\leq 0.03 \text { to } \\
0.12\end{array}$ & $\leq 0.03$ & 0.06 & $\begin{array}{l}0.25 \text { to } \\
1\end{array}$ & 0.5 & 1 & [174] \\
\hline & Peni-S & 216 & ORI & $\begin{array}{l}\leq 0.008 \\
\text { to } 0.12\end{array}$ & $\leq 0.008$ & 0.03 & & & & [173] \\
\hline & Peni-R & 86 & ORI & $\begin{array}{l}\leq 0.008 \\
\text { to } 0.25\end{array}$ & 0.015 & 0.06 & & & & [173] \\
\hline \multirow[t]{3}{*}{ Streptococcus pyogenes } & All & 449 & TLV & $\begin{array}{l}\leq 0.015 \\
\text { to } 0.12\end{array}$ & $\leq 0.015$ & 0.03 & & & & {$[40]$} \\
\hline & All & 132 & ORI & $\begin{array}{l}\leq 0.0005 \\
\text { to } 0.5\end{array}$ & 0.03 & 0.25 & $\begin{array}{l}0.25 \text { to } \\
1\end{array}$ & 0.5 & 0.5 & {$[50]$} \\
\hline & All & 155 & DAL & $\begin{array}{l}\leq 0.03 \text { to } \\
0.12\end{array}$ & $\leq 0.03$ & $\leq 0.03$ & $\begin{array}{l}0.25 \text { to } \\
0.5\end{array}$ & 0.25 & 0.5 & [174] \\
\hline \multirow[t]{2}{*}{ Streptococcus agalactiae } & All & 393 & TLV & $\begin{array}{l}\leq 0.015 \\
\text { to } 0.12\end{array}$ & 0.03 & 0.06 & & & & {$[40]$} \\
\hline & All & 153 & DAL & $\begin{array}{l}\leq 0.03 \text { to } \\
0.25\end{array}$ & $\leq 0.03$ & 0.12 & $\begin{array}{c}0.25 \text { to } \\
1\end{array}$ & 0.5 & 0.5 & {$[174]$} \\
\hline
\end{tabular}

$D A L$ dalbavancin, $M I C$ minimum inhibitory concentration, $M I C_{50}$ MIC at which $50 \%$ of bacteria are inhibited, $M I C_{90}$ MIC at which $90 \%$ of bacteria are inhibited, ORI oritavancin, Peni-R penicillin-resistant, Peni-S penicillin susceptible, TLV telavancin, VAN vancomycin, VanA VanA phenotype of vancomycin resistance, $\operatorname{VanB}$ VanB phenotype of vancomycin resistance, $V A N-S$ vancomycin susceptible

${ }^{a}$ Limited to studies published from 2012 and July 2015, where lipoglycopeptides where tested in the presence of $0.002 \%$ polysorbate-80 and compared to VAN

of cells was limited to drug amounts for which cellular concentrations were of the same order of magnitude as those measured in patients, no specific sign of intoxication of macrophages was evidenced, including with respect to phagocytic or killing capacities or oxidant species production [77, 78]. Telavancin also caused cellular lipidosis, but to a much lower extent than oritavancin, related to its lower cellular accumulation [79].

\section{Pharmacokinetics and Pharmacodynamics}

\subsection{In Vitro Pharmacodynamics}

Oritavancin shows bactericidal activity which is rapid (1 h) against Streptococcus pyogenes, MRSA, and VRSA, slower (10-20 h) against daptomycin-resistant S. aureus, and VRE and vancomycin-susceptible enterococci (VSE), or even slower $(24 \mathrm{~h})$ against VISA in in vitro models of continuous exposure to the drug [80-82]. It was also rapidly $(1 \mathrm{~h})$ bactericidal against Streptococcus pneumoniae in an in vitro pharmacodynamic model [83]. Moreover, it remains bactericidal against high inocula of vancomycin-susceptible $S$. aureus as well as against hetero-VISA (h-VISA), but not against VISA at a concentration mimicking the free maximum concentration $\left(C_{\max }\right)$ reached in the serum of patients after a single dose of $1200 \mathrm{mg}$ [84, 85].

Telavancin also proved more rapidly bactericidal against MSSA, MRSA, and h-VISA than against VISA, VRSA, or coagulase-negative $S$. aureus $[35,86]$. It remains bactericidal against $\mathrm{h}$-VISA at high inoculum but after a longer 
incubation time $(16 \mathrm{~h})$ [87]. In an in vitro pharmacodynamic model mimicking human exposure to $10 \mathrm{mg} / \mathrm{kg}$, telavancin was bactericidal after $8 \mathrm{~h}$ against h-VISA, linezolid-resistant $S$. aureus, and daptomycin-resistant S. aureus, but was bactericidal after $24 \mathrm{~h}$ against VISA [88]. In contrast, telavancin is bacteriostatic on $C$. difficile [54].

In sharp contrast, dalbavancin is slowly bactericidal against $S$. aureus and $S$. pyogenes, a 24-h incubation being needed to observe bacterial eradication [89].

Synergy has been demonstrated in vitro between oritavancin and aminoglycosides, $\beta$-lactams, linezolid, or rifampin against MRSA or enterococci [90-93] as well as between telavancin and $\beta$-lactams, aminoglycosides, or rifampin against MRSA [94, 95], or dalbavancin and oxacillin against MRSA [96].

\subsection{Animal Pharmacodynamic Models}

Ambrose and coworkers have reviewed the activity of oritavancin in animal models [97]. Oritavancin is as or more effective than comparators (vancomycin, daptomycin) for the treatment of MRSA or Enterococcus endocarditis, while at the same time better in preventing relapses $[98,99]$. It is also very effective for the treatment of MRSA pneumonia or bacteremia. It is more active than vancomycin against $C$. difficile infection by the oral route in the hamster model and prevents spore germination [57, 58]. A high single dose reduced bacterial burden in a catheter infection by VanA enterococci [100] as well as in pneumonia or in meningitis caused by pneumococci [101, 102]. A single dose is also protective against anthrax in a murine model of spore inhalation [103].

Telavancin activity in animals has also been recently reviewed [104]. In brief, its efficacy and superiority compared with vancomycin or daptomycin has been documented in murine models of bacteremia or pneumonia by MRSA [105, 106], in murine subcutaneous infection models, in rabbit endocarditis caused by MRSA, VISA, or daptomycin non-susceptible staphylococci [107-109], as well as in rabbit meningitis caused by penicillin-resistant pneumococcus $[110,111]$. It was equivalent to vancomycin or linezolid in a model of rabbit osteomyelitis caused by MRSA [112].

With respect to dalbavancin, it showed activity in a rat granuloma pouch infection model by MSSA and MRSA [113], in neutropenic murine thigh and lung infection models by S. aureus or S. pneumoniae [114], in rabbit endocarditis caused by $S$. aureus, including strains with reduced susceptibility to glycopeptides [115], in foreign body infection by MRSA in guinea pigs [116], and in an anthrax inhalation model [117].

\subsection{Pharmacokinetics/Pharmacodynamics for Dosing Optimization}

In neutropenic mice thigh infection models aimed at determining pharmacokinetic/pharmacodynamic (PK/PD) parameters predictive of efficacy, free area under the concentration-time curve (AUC)/MIC is the best predictor of efficacy for the three drugs, together with the $C_{\max } / \mathrm{MIC}$ ratio for oritavancin, based on its highly bactericidal character [104, 114, 118, 119].

For oritavancin, its concentration-dependent bactericidal activity combined with its prolonged half-life (see Sects. 4.1 and 4.4) has led to the selection of a $1200 \mathrm{mg}$ singledose treatment [97], which allows maximization of the $C_{\max } / \mathrm{MIC}$ and AUC/MIC ratio while at the same time facilitating drug administration. In population pharmacokinetic studies of patients treated with this dose, the $C_{\max }$ reaches $138 \mathrm{mg} / \mathrm{L}(20.7 \mathrm{mg} / \mathrm{L}$ for free fraction) and the AUC reaches $1110 \mathrm{mg} \cdot \mathrm{h} / \mathrm{L}$ (165 for free fraction) after

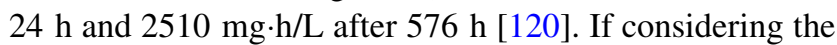
PK/PD breakpoint of $0.125 \mathrm{mg} / \mathrm{L}$ established by both European Committee on Antimicrobial Susceptibility Testing (EUCAST) and FDA for S. aureus (Table 2), the $f C_{\max } / \mathrm{MIC}$ and $f \mathrm{AUC}_{24} / \mathrm{MIC}$ are as high as 165 and $1352 \mathrm{~h}$, respectively, after administration of $1200 \mathrm{mg}$ to humans. Simulating this dose in an in vitro pharmacodynamic model of infection by MRSA generated considerable bactericidal effect [121].

For telavancin, an $\mathrm{AUC}_{24} / \mathrm{MIC}$ ratio of $219 \mathrm{~h}$ has been proposed as the PK/PD target associated with a $1 \log _{10}$ CFU (colony-forming units) decrease in models of infection by MRSA in neutropenic mice. This value could be achieved in patients with normal renal function receiving a daily dose of $10 \mathrm{mg} / \mathrm{kg}$ for MICs $\leq 2 \mathrm{mg} / \mathrm{L}$ [122]. It was nevertheless challenged based on inconsistencies in the reported MIC values for the MRSA strain used for this study [123]. Accordingly, a lower susceptibility breakpoint of $1 \mathrm{mg} / \mathrm{L}$ had first been selected by the FDA, allowing a target AUC/MIC of 438 to be reached. Yet this breakpoint has recently been revised by both the FDA and the EUCAST to a value of $0.125 \mathrm{mg} / \mathrm{L}$ based on the new procedure established by CLSI for determining the MIC in the presence of polysorbate-80 (see Table 2).

For dalbavancin, Monte-Carlo simulations combining pharmacokinetic and MIC data from phase III trials suggest a PK/PD breakpoint of $1 \mathrm{mg} / \mathrm{L}$ for staphylococci, allowing a $f \mathrm{AUC}_{14 \text { days }} / \mathrm{MIC}>1000 \mathrm{~h}$ to be reached [114, 124], but, again, these were based on MICs determined in the absence of polysorbate- 80 . The current susceptibility breakpoint is therefore much lower $(0.12 \mathrm{mg} / \mathrm{L}$; see Table 2). 
Table 2 Current susceptibility breakpoints for new lipoglycopeptides as compared with vancomycin

\begin{tabular}{|c|c|c|c|c|c|}
\hline \multirow[t]{2}{*}{ Antibacterial } & \multirow[t]{2}{*}{ Bacterial species } & \multicolumn{2}{|c|}{ US FDA } & \multicolumn{2}{|c|}{ EUCAST } \\
\hline & & $S \leq$ & $R \geq$ & $S \leq$ & $R>$ \\
\hline \multirow[t]{4}{*}{ Vancomycin } & Coagulase-negative staphylococci (CONS) & 4 & 32 & 4 & 4 \\
\hline & Streptococci (other than pneumoniae) & 1 & NA & 2 & 2 \\
\hline & Enterococci & 4 & 32 & 4 & 4 \\
\hline & Other staphylococcal or streptococcal species & 2 & 16 & 2 & 2 \\
\hline \multirow[t]{3}{*}{ Oritavancin } & Staphylococci & 0.12 & NA & 0.125 & 0.125 \\
\hline & Streptococci & 0.25 & NA & 0.25 & 0.25 \\
\hline & Enterococcus faecalis & 0.12 & NA & 0.125 & 0.125 \\
\hline \multirow[t]{3}{*}{ Telavancin } & Staphylococci & 0.12 & NA & 0.125 & 0.125 \\
\hline & Streptococci & 0.12 & NA & & \\
\hline & E. faecalis & 0.25 & NA & & \\
\hline \multirow[t]{2}{*}{ Dalbavancin } & Staphylococci & 0.12 & NA & 0.125 & 0.125 \\
\hline & Streptococci & 0.12 & NA & & \\
\hline
\end{tabular}

EUCAST European Committee on Antimicrobial Susceptibility Testing, FDA Food and Drug Administration, $N A$ not applicable (no resistant isolate described so far), $R$ resistant, $S$ susceptible

\subsection{Human Pharmacokinetics and Dosing}

The pharmacokinetic profile of the three drugs after administration of registered doses to humans is illustrated in Table 3. As compared with vancomycin, the main characteristic of these drugs is their long half-life, which is related to their high protein binding but also to their capacity to accumulate within eukaryotic cells. The halflife is particularly prolonged (longer than $200 \mathrm{~h}$ ) for oritavancin and dalbavancin, justifying their administration schedules (single or two doses, respectively). Remarkably, oritavancin shows a distribution volume of $87 \mathrm{~L}$ and reaches concentrations in alveolar macrophages as high as 142 -fold its serum concentration. Dalbavancin reaches concentrations of 6.3 and $4.1 \mu \mathrm{g} / \mathrm{g}$ in articular tissues $12 \mathrm{~h}$ and 4 weeks, respectively, after the administration of $1000 \mathrm{mg}$. Subsequent administrations of $500 \mathrm{mg}$ per week for 7 weeks did not cause drug accumulation and was welltolerated, warranting investigation into interest in the use of this drug for the treatment of osteomyelitis [125].

While oritavancin does not require any dose adaptation in cases of impaired renal function, both telavancin and dalbavancin do need an adjustment. In patients with hepatic insufficiency, no dose adjustment is recommended for oritavancin $[6,120]$ or telavancin $[10,126]$ for Child-Pugh grades A-B, or for dalbavancin for Child-Pugh grade A [6, $10,14]$. Caution should be exercised in case of more severe dysfunction, as no specific data are available. These drugs cannot be administered to pregnant (class $\mathrm{C}$ ) or breastfeeding women, or to children. However, a recent phase I, open-label study conducted with dalbavancin on children from 12 to 17 years old concluded that similar plasma exposures were obtained after administration of $1000 \mathrm{mg}$ or $15 \mathrm{mg} / \mathrm{kg}$, with acceptable tolerance [127]. AUC exposures were, however, $30 \%$ lower than in adults who received the same dose, which is consistent with enhanced renal and/or hepatic elimination in healthy adolescents. Other open-label studies focusing on the pharmacokinetics and safety of oritavancin (NCT02134301 [128]) and telavancin (NCT02013141 [129]) in patients younger than 18 or 17 years, respectively, are ongoing.

\section{Clinical Efficacy}

\subsection{Registered Indications}

Table 4 shows the main clinical trials that led to the registration of lipoglycopeptides for the treatment of acute bacterial skin and skin structure infections and for hospitalacquired pneumonia (telavancin only). The reader is referred to recent reviews that have examined these studies in details (oritavancin [32, 130], telavancin [131, 132], and dalbavancin [133, 134]).

Globally speaking, and focusing on acute bacterial skin and skin structure infections (a common indication for the three drugs), phase II and III trials concluded that the investigated drug was non-inferior to conventional therapy [vancomycin IV, anti-staphylococcal penicillin, linezolid (with possible oral switch)]. The safety profile was also globally comparable to that of the comparators. A post hoc analysis was recently published for telavancin, in which data from the ATLAS [Assessment of Telavancin in cSSSI (complicated skin and skin structure infection)] trials were reanalyzed taking into consideration the recent guidance from the FDA concerning studies evaluating antibacterials 
Table 3 Pharmacokinetics and dosing of new lipoglycopeptides

\begin{tabular}{|c|c|c|c|}
\hline \multirow[t]{2}{*}{ Parameter } & \multicolumn{3}{|l|}{ Antibacterial } \\
\hline & Oritavancin & Telavancin $^{\mathrm{a}}$ & Dalbavancin $^{\mathrm{b}}$ \\
\hline \multicolumn{4}{|l|}{ Dosing } \\
\hline Creatinine clearance $>50 \mathrm{~mL} / \mathrm{min}$ & $1200 \mathrm{mg}$ single dose; $3 \mathrm{~h}$ infusion [6] & 10 mg/kg q24h [10] & $1000 \mathrm{mg}$ day $1+500 \mathrm{mg}$ day 7 [14] \\
\hline Creatinine clearance $30-50 \mathrm{~mL} / \mathrm{min}$ & $1200 \mathrm{mg}$ single dose; $3 \mathrm{~h}$ infusion [6] & $7.5 \mathrm{mg} / \mathrm{kg}$ q24h [10] & $1000 \mathrm{mg}$ day $1+500 \mathrm{mg}$ day 7 [14] \\
\hline Creatinine clearance $10-<30 \mathrm{~mL} / \mathrm{min}$ & $1200 \mathrm{mg}$ single dose; $3 \mathrm{~h}$ infusion [6] & $10 \mathrm{mg} / \mathrm{kg} \mathrm{q} 48 \mathrm{~h}[10]$ & $750 \mathrm{mg}$ day $1+375 \mathrm{mg}$ day 7 [14] \\
\hline$C_{\max }(\mathrm{mg} / \mathrm{L})$ & $138[6]$ & $94 / 108[10]$ & $287[14]$ \\
\hline $\mathrm{AUC}_{24}(\mathrm{mg} \cdot \mathrm{h} / \mathrm{L})$ & $1110[6]$ & $666 / 780[10]$ & $3185[14]$ \\
\hline $\mathrm{AUC}_{\infty}(\mathrm{mg} \cdot \mathrm{h} / \mathrm{L})$ & $2800[6]$ & 747/NA [10] & $23,443[14]$ \\
\hline Protein binding (\%) & $85[6]$ & $90[10]$ & $93[14]$ \\
\hline$t_{1 / 2 \alpha}(\mathrm{h})$ & $2.29[6]$ & $8 / 8.1[10]$ & NA \\
\hline$t_{1 / 2 \beta}(\mathrm{h})$ & $13.4[6]$ & & NA \\
\hline$t_{1 / 2 \gamma}(\mathrm{h})$ & $245[6]$ & & $346[14]$ \\
\hline Clearance $(\mathrm{L} / \mathrm{h})$ & $0.445[6]$ & $0.97 / 0.90[10]$ & $0.015[14]$ \\
\hline$V_{\mathrm{ss}}(\mathrm{L})$ & $87.6[6]$ & $10.15 / 9.31[10]$ & $7.93[176]$ \\
\hline Macrophages/plasma & $142.7^{\mathrm{C}}[177]$ & $6.67(24 \mathrm{~h})[178]$ & NA \\
\hline ELF/serum & $4.6^{\mathrm{c}}[177]$ & 0.7 [179] & NA \\
\hline
\end{tabular}

$A U C_{\infty}$ area under the concentration-time curve from time zero to infinity, $A U C_{24}$ area under the concentration-time curve from time zero to $24 \mathrm{~h}, C_{\max }$ maximum concentration, $E L F$ epithelial lining fluid, $N A$ not available, $q x h$ every $x \mathrm{~h}, t_{1 / 2 \alpha}$ initial or disposition half-life, $t_{1 / 2 \beta}$ terminal elimination half-life in a 2-compartment model, $t_{1 / 2 \gamma}$ terminal elimination half-life in a 3-compartment model, $V_{s s}$ apparent volume of distribution at steady state

${ }^{\text {a }}$ Pharmacokinetic data given for single dose/multiple dose of $10 \mathrm{mg} / \mathrm{kg}$

b Pharmacokinetic data for a single dose of $1000 \mathrm{mg}$

c For an $800 \mathrm{mg}$ dose

for acute bacterial skin and skin structure infections that was issued after the performance of these trials (namely, inclusion of patients with lesion size $\geq 75 \mathrm{~cm}^{2}$ and exclusion of patients with ulcers or burns) [135]. The adoption of an updated test-of-cure clinical response $(\geq 90 \%$ reduction in lesion size, no increase in lesion size since day 3 , and no requirement for additional antibacterialcs/significant surgical procedures) concluded that there was equivalence between telavancin- and vancomycin-treated patients (68.0 vs. $63.3 \%$ cure rates).

Phase II studies determined the optimal dosing regimen as being a single dose of $1200 \mathrm{mg}$ for oritavancin (SIMPLIFI trial [3]), a $1000 \mathrm{mg}$ dose at day 1 followed by a $500 \mathrm{mg}$ dose at day 7 for dalbavancin [136], and a $10 \mathrm{mg} /$ $\mathrm{kg}$ daily dose for telavancin (FAST 2 trial [137]). Thus, a possible advantage of oritavancin and dalbavancin resides in their simplified therapeutic scheme, which may even allow their use for home therapy [138, 139].

Telavancin is also indicated for HABP and VABP caused by susceptible isolates of $S$. aureus (including methicillin-susceptible and -resistant isolates), based on the ATTAIN (Assessment of Telavancin for Treatment of Hospital-Acquired Pneumonia) phase III trials, which showed non-inferiority to vancomycin for this indication [140]. A secondary objective of the ATTAIN trials was to perform a pooled analysis of the two studies with respect to telavancin superiority compared with vancomycin in patients with pneumonia attributable to MRSA [140]. The clinical response between the two groups was similar, but cure rates were higher in the telavancin group when considering patients with mono-microbial infection due to S. aureus (both MRSA and MSSA; 84.2 vs. $74.3 \%$ success rate for telavancin and vancomycin, respectively) or patients infected with strains showing a vancomycin MIC $>1 \mathrm{mg} / \mathrm{L}$ (87.2 vs. $74.3 \%$ success rate for telavancin and vancomycin, respectively). In contrast, lower cure rates were observed in the telavancin-treated group for patients with mixed infections $(66.2$ vs. $79.4 \%$ success rate for telavancin and vancomycin, respectively); the difference disappeared if patients who received adequate Gramnegative coverage were considered (66.3 vs. $66.7 \%$ success rate for telavancin and vancomycin, respectively) [141]. Of note, the clinical success of telavancin was also lower than that of vancomycin in the subgroup of patients with severe renal impairment (creatinine clearance $<30 \mathrm{~mL} / \mathrm{min}$ ) or pre-existing acute renal failure, including 
Table 4 Main clinical trials involving new lipoglycopeptides for their current indications

\begin{tabular}{|c|c|c|c|c|c|c|}
\hline Phase & $\begin{array}{l}\text { Study name and/or } \\
\text { ClinicalTrials.gov } \\
\text { identifier }\end{array}$ & $\begin{array}{l}\text { Study arm (number } \\
\text { of patients; ITT) }\end{array}$ & $\begin{array}{l}\text { Comparator } \\
\text { (number of } \\
\text { patients; ITT) }\end{array}$ & Indications & Outcomes & References \\
\hline II & $\begin{array}{l}\text { SIMPLIFI } \\
\text { NCT00514527 }\end{array}$ & $\begin{array}{l}\text { ORI } 1200 \mathrm{mg} \\
\text { day } 1(99)\end{array}$ & $\begin{array}{l}\text { ORI } 800 \mathrm{mg} \text { day } 1 \\
{[+400 \mathrm{mg} \text { day } 5]} \\
(100) \\
\text { ORI } 200 \mathrm{mg} / \mathrm{day} \\
\text { for } 3-7 \text { days } \\
(103)\end{array}$ & $\begin{array}{l}\text { Acute bacterial skin and } \\
\text { skin structure infections } \\
\text { (wound infections, } \\
\text { major abscess, and } \\
\text { cellulitis) }\end{array}$ & $\begin{array}{l}\text { Non-inferiority (15\% } \\
\text { margin): } \\
\text { - Clinical response at } \\
\text { days } 21-29\end{array}$ & [3] \\
\hline III & $\begin{array}{l}\text { SOLO } 1 \\
\text { NCT01252719 }\end{array}$ & $\begin{array}{l}\text { ORI } 1200 \mathrm{mg} \\
\text { day } 1(475)\end{array}$ & $\begin{array}{l}\text { VAN } 1 \mathrm{~g} \text { or } 15 \mathrm{mg} / \\
\mathrm{kg} \text { bid } 7-10 \text { days } \\
(479)\end{array}$ & $\begin{array}{l}\text { Acute bacterial skin and } \\
\text { skin structure infections } \\
\text { (wound infections, } \\
\text { major abscess, and } \\
\text { cellulitis) }\end{array}$ & $\begin{array}{l}\text { Non-inferiority }(10 \% \\
\text { margin): } \\
\text { - No spreading or } \\
\text { reduction of lesion size } \\
\text { measured at } 48-72 \mathrm{~h}, \\
\text { absence of fever, and no } \\
\text { need for rescue } \\
\text { antibacterials } \\
\text { - Clinical cure within } \\
7-14 \text { days } \\
\text { - } \geq 20 \% \text { reduction in } \\
\text { lesion size at } 48-72 \mathrm{~h}\end{array}$ & [159] \\
\hline III & $\begin{array}{l}\text { SOLO } 2 \\
\text { NCT01252732 }\end{array}$ & $\begin{array}{l}\text { ORI } 1200 \mathrm{mg} \\
\text { day } 1(503)\end{array}$ & $\begin{array}{l}\text { VAN } 1 \mathrm{~g} \text { or } 15 \mathrm{mg} / \\
\mathrm{kg} \text { bid } 7-10 \text { days } \\
(502)\end{array}$ & $\begin{array}{l}\text { Acute bacterial skin and } \\
\text { skin structure infections } \\
\text { (wound infections, } \\
\text { major abscess, and } \\
\text { cellulitis) }\end{array}$ & $\begin{array}{l}\text { Non-inferiority (10\% } \\
\text { margin): } \\
\text { - No spreading or } \\
\text { reduction of lesion size } \\
\text { measured at } 48-72 \mathrm{~h}, \\
\text { absence of fever, and no } \\
\text { need for rescue } \\
\text { antibacterials } \\
\text { - Clinical cure within } \\
7-14 \text { days } \\
\text { - } \geq 20 \% \text { reduction in } \\
\text { lesion size at } 48-72 \mathrm{~h}\end{array}$ & [158] \\
\hline II & FAST 1 & $\begin{array}{l}\text { TLV } 7.5 \mathrm{mg} / \mathrm{kg} \\
\text { q24h (84) }\end{array}$ & $\begin{array}{l}\text { Antistaphylococcal } \\
\text { penicillin } 2 \mathrm{~g} \mathrm{q} 6 \mathrm{~h} \\
\text { or VAN } 1 \mathrm{~g} \mathrm{q} 12 \mathrm{~h} \\
(85)\end{array}$ & $\begin{array}{l}\text { Complicated skin and } \\
\text { skin structure infections } \\
\text { (major abscess } \\
\text { requiring surgical } \\
\text { drainage; deep, } \\
\text { extensive cellulitis; } \\
\text { infected wound or } \\
\text { ulcer; infected burn) }\end{array}$ & $\begin{array}{l}\text { Non-inferiority: } \\
\text { - Clinical evaluation at } \\
\text { EOT and TOC (7-14 } \\
\text { days after end of } \\
\text { therapy) visits }\end{array}$ & [180] \\
\hline II & FAST 2 & $\begin{array}{l}\text { TLV } 10 \mathrm{mg} / \mathrm{kg} \\
\text { q24h (103) }\end{array}$ & $\begin{array}{l}\text { Antistaphylococcal } \\
\text { penicillin } 2 \mathrm{~g} \mathrm{q} 6 \mathrm{~h} \\
\text { or VAN } 1 \mathrm{~g} \mathrm{q} 12 \mathrm{~h} \\
(98)\end{array}$ & $\begin{array}{l}\text { Complicated skin and } \\
\text { skin structure infections } \\
\text { (major abscess } \\
\text { requiring surgical } \\
\text { drainage; deep, } \\
\text { extensive cellulitis; } \\
\text { infected wound or } \\
\text { ulcer; infected burn) }\end{array}$ & $\begin{array}{l}\text { Non-inferiority: } \\
\text { - Clinical evaluation at } \\
\text { EOT and TOC } \\
\text { (7-14 days after end of } \\
\text { therapy) visits }\end{array}$ & [137] \\
\hline III & $\begin{array}{l}\text { ATLAS } 1 \text { and } 2 \\
\text { NCT00091819 } \\
\text { NCT00107978 }\end{array}$ & $\begin{array}{l}\text { TLV } 10 \mathrm{mg} / \mathrm{kg} \\
\text { q24h for } \\
7-14 \text { days (928) }\end{array}$ & $\begin{array}{l}\text { VAN } 1 \text { g q12h for } \\
7-14 \text { days (939) }\end{array}$ & $\begin{array}{l}\text { Complicated skin and } \\
\text { skin structure infections } \\
\text { (major abscess } \\
\text { requiring surgical } \\
\text { drainage; deep, } \\
\text { extensive cellulitis; } \\
\text { infected wound or } \\
\text { ulcer; infected burn) }\end{array}$ & $\begin{array}{l}\text { Non-inferiority (10\% } \\
\text { margin): } \\
\text { - Clinical evaluation at } \\
\text { TOC ( } 7-14 \text { days after } \\
\text { end of therapy) visits }\end{array}$ & [156] \\
\hline
\end{tabular}


Table 4 continued

\begin{tabular}{|c|c|c|c|c|c|c|}
\hline Phase & $\begin{array}{l}\text { Study name and/or } \\
\text { ClinicalTrials.gov } \\
\text { identifier }\end{array}$ & $\begin{array}{l}\text { Study arm (number } \\
\text { of patients; ITT) }\end{array}$ & $\begin{array}{l}\text { Comparator } \\
\text { (number of } \\
\text { patients; ITT) }\end{array}$ & Indications & Outcomes & References \\
\hline III & $\begin{array}{l}\text { ATTAIN } 1 \text { and } 2 \\
\text { NCT00107952 } \\
\text { NCT00124020 }\end{array}$ & $\begin{array}{l}\text { TLV } 10 \mathrm{mg} / \mathrm{kg} \\
\text { q24h for } \\
7-21 \text { days }(749)\end{array}$ & $\begin{array}{l}\text { VAN } 1 \text { g q12h for } \\
7-21 \text { days (754) }\end{array}$ & $\begin{array}{l}\text { Pneumonia acquired after } \\
48 \mathrm{~h} \text { in an inpatient } \\
\text { acute or chronic care } \\
\text { facility or that } \\
\text { developed within } \\
7 \text { days after being } \\
\text { discharged }\end{array}$ & $\begin{array}{l}\text { Non-inferiority ( } 20 \% \\
\text { margin): } \\
\text { Improvement or lack of } \\
\text { progression of baseline } \\
\text { radiographic findings at } \\
\text { end of EOT and } \\
\text { resolution of signs and } \\
\text { symptoms of } \\
\text { pneumonia at TOC visit } \\
\text { Superiority compared } \\
\text { with vancomycin } \\
\text { treatment in patients } \\
\text { with pneumonia due to } \\
\text { MRSA (not met) }\end{array}$ & [140] \\
\hline $\begin{array}{l}\text { II } \\
\text { (open- } \\
\text { label) }\end{array}$ & None & $\begin{array}{c}\text { DAL } 1 \mathrm{~g} \text { day } \\
1+500 \mathrm{mg} \\
\text { day } 7(20)\end{array}$ & $\begin{array}{l}\text { DAL } 1100 \mathrm{mg} \\
\text { day } 1(20) \text { or } \\
\text { standard of care } \\
\text { (21) }\end{array}$ & $\begin{array}{l}\text { Complicated skin and } \\
\text { skin structure infections } \\
\text { (major abscess, infected } \\
\text { ulcer, a major burn } \\
\text { deep and extensive } \\
\text { cellulitis) }\end{array}$ & $\begin{array}{l}\text { Clinical response at the } \\
\text { TOC visit (day } 24 \text { for } \\
\text { 1-dose DAL, day } 34 \text { for } \\
\text { 2-dose DAL, and } \\
2 \text { weeks after the last } \\
\text { dose for comparators) }\end{array}$ & [136] \\
\hline III & None & $\begin{array}{l}\text { DAL } 1 \mathrm{~g} \\
\text { day } 1+500 \mathrm{mg} \\
\text { day } 7(571)\end{array}$ & $\begin{array}{l}\text { LZD } 600 \mathrm{mg} \text { bid } \\
\text { (iv or po) for } \\
14 \text { days }(283)\end{array}$ & $\begin{array}{l}\text { Complicated skin and } \\
\text { skin structure infections } \\
\text { (major abscesses, major } \\
\text { burns, traumatic or } \\
\text { surgical wound } \\
\text { infections, and deep } \\
\text { skin/skin-structure } \\
\text { infection) or known or } \\
\text { suspected to be caused } \\
\text { by MRSA }\end{array}$ & $\begin{array}{l}\text { Non-inferiority (12.5\% } \\
\text { margin): } \\
\text { - Evaluation of clinical } \\
\text { and microbiological } \\
\text { responses, both } \\
\text { separately and } \\
\text { combined, at the EOT } \\
\text { and TOC visits }\end{array}$ & [181] \\
\hline III & $\begin{array}{l}\text { DISCOVER } 1 \\
\text { NCT01339091 }\end{array}$ & $\begin{array}{c}\text { DAL } 1 \text { g day } \\
1+500 \mathrm{mg} \\
\text { day } 7(288)\end{array}$ & $\begin{array}{l}\text { VAN } 1 \mathrm{~g} \text { or } 15 \mathrm{mg} / \\
\mathrm{kg} \text { bid for } 3 \text { days } \\
\text { with possible } \\
\text { switch to oral } \\
\text { LZD } 600 \mathrm{mg} \text { bid } \\
\text { up to } 10-14 \text { days } \\
\text { (285) }\end{array}$ & $\begin{array}{l}\text { Acute bacterial skin and } \\
\text { skin structure infections } \\
\text { (wound infections, } \\
\text { major abscess, and } \\
\text { cellulitis) }\end{array}$ & $\begin{array}{l}\text { Non-inferiority }(10 \% \\
\text { margin): } \\
\text { - Early clinical response } \\
\text { at } 48-72 \mathrm{~h} \text { : cessation of } \\
\text { spread of the erythema } \\
\text { associated with the } \\
\text { infection; temperature } \\
\leq 37.6{ }^{\circ} \mathrm{C}\end{array}$ & [182] \\
\hline III & $\begin{array}{l}\text { DISCOVER } 2 \\
\text { NCT01431339 }\end{array}$ & $\begin{array}{l}\text { DAL } 1 \mathrm{~g} \text { day } \\
1+500 \mathrm{mg} \text { day } \\
7(371)\end{array}$ & $\begin{array}{l}\text { VAN } 1 \mathrm{~g} \text { or } 15 \mathrm{mg} / \\
\mathrm{kg} \text { bid for } 3 \text { days } \\
\text { with possible } \\
\text { switch to oral } \\
\text { LZD } 600 \mathrm{mg} \text { bid } \\
\text { up to } 10-14 \text { days } \\
\text { (368) }\end{array}$ & $\begin{array}{l}\text { Acute bacterial skin and } \\
\text { skin structure infections } \\
\text { (wound infections, } \\
\text { major abscess, and } \\
\text { cellulitis) }\end{array}$ & $\begin{array}{l}\text { Non-inferiority }(10 \% \\
\text { margin): } \\
\text { - Early clinical response } \\
\text { at } 48-72 \mathrm{~h} \text { : cessation of } \\
\text { spread of the erythema } \\
\text { associated with the } \\
\text { infection; temperature } \\
\leq 37.6{ }^{\circ} \mathrm{C}\end{array}$ & [182] \\
\hline
\end{tabular}

bid twice daily, DAL dalbavancin, DISCOVER dalbavancin for infections of the skin compared to vancomycin at an early response, EOT end of therapy, ITT intent-to-treat, $i v$ intravenous, LZD linezolid, MRSA methicillin-resistant Staphylococcus aureus, ORI oritavancin, po oral, $q x h$ every $x \mathrm{~h}, T L V$ telavancin, TOC test of cure, VAN vancomycin

those on hemodialysis [142], but was equivalent for both drugs when excluding these subgroups from the analysis [143]. In Europe, telavancin is therefore not recommended for the treatment of hospital-acquired pneumonia in these circumstances [11].

\subsection{Other Types of Infections}

The usefulness of these drugs in other potential indications has been examined in small series of patients or even in case reports. 


\subsubsection{Oritavancin}

The pharmacokinetics and pharmacodynamics of oritavancin were evaluated in 55 patients with $S$. aureus bacteremia for both microbiological and clinical responses [144]. Bayesian oritavancin exposure predictions were derived using a validated population pharmacokinetic model for treatments with $5-10 \mathrm{mg} / \mathrm{kg}$ of body weight/day; they identified a breakpoint of the percentage of the dosing interval duration for which free-drug concentrations were above the MIC (free-drug \% time $>$ MIC) of $22 \%$ for both microbiological and clinical response. Although of interest, this study was performed before the new therapeutic scheme of oritavancin (single dose) was established, limiting its applicability.

\subsubsection{Telavancin}

Telavancin $(10 \mathrm{mg} / \mathrm{kg}$ every $24 \mathrm{~h}$, adapted to renal function; see Table 3) was compared with vancomycin or an anti-staphylococcal penicillin in a phase II trial for the treatment of uncomplicated bacteremia, half of the cases of which were related to catheter infections [ASSURE (Telavancin for Treatment of Uncomplicated S. aureus Bacteremia) trial] [145]. Of the 60 enrolled patients, only eight (telavancin arm) and nine (comparator arm) were clinically evaluable because they had to fulfill a series of criteria after the administration of the first dose to continue the treatment in order to ensure the non-complicated character of the infection. Comparable cure rates were recorded in the two arms ( 88 and $89 \%$ ), warranting further studies in this indication. Of note, among patients infected by Gram-positive pathogens only enrolled in the two ATTAIN trials, cure rates for the subgroup of bacteremic patients was similar in both treatment groups $(41 \%$ for telavancin vs. $40 \%$ for vancomycin), with identical mortality rates [146].

A few case reports have illustrated the efficacy of telavancin in other specific indications. In a patient with endocarditis, linezolid (microbiologically effective but thrombocytopenia developed during the 26 days of treatment) was successfully replaced with telavancin $(10 \mathrm{mg} /$ $\mathrm{kg}$ /day), with no safety concern after 3 weeks of treatment [147]. The status of another patient who presented with a pacemaker lead infection caused by VISA worsened after successive treatment with vancomycin and daptomycin ( $8 \mathrm{mg} / \mathrm{kg}$, increased to $10 \mathrm{mg} / \mathrm{kg}$ ) but she rapidly became non-bacteremic once daptomycin had been replaced with telavancin, with complete cure achieved after 8 weeks of therapy [148]. Following 2 weeks of unsuccessful therapy with a combination of vancomycin and oral rifampicin in a patient with methicillin-resistant $S$. epidermidis prosthetic joint infection following bilateral total knee replacement, the infection was cured with telavancin $10 \mathrm{mg} / \mathrm{kg}$ for 6 weeks combined with oral rifampicin [149]. Three patients with osteomyelitis who did not respond to vancomycin therapy were successfully treated with telavancin for 6-10 weeks, with no evidence of recurrence after several months [150]. A fourth patient showed an improved clinical status after 4 weeks of treatment, but his serum creatinine also rose, which justified a switch to tigecycline therapy [150]. Likewise, an 18-year-old male with spina bifida who had chronic osteomyelitis received antibiotherapy with multiple antimicrobials during 133 days. Cure and absence of recurrence were eventually achieved with a regimen consisting of telavancin $750 \mathrm{mg} /$ day for 42 days, meropenem for 50 days, and oral rifampin for 50 days [151].

\subsubsection{Dalbavancin}

A phase II study compared dalbavancin $(n=33 ; 1000 \mathrm{mg}$ loading dose on day 1 and $500 \mathrm{mg}$ on day 8) with vancomycin $(n=34 ; 1000 \mathrm{mg}$ every $12 \mathrm{~h}$ ) for the treatment of catheter-related bloodstream infections [152] and concluded that dalbavancin was superior (clinical success rate: 87 vs. $50 \%$; microbiological success rate: 95.7 vs. $78.6 \%$ ). In both arms, success was higher when catheters were removed. Dalbavancin also proved effective for the treatment of catheter-related septic phlebitis caused by MSSA in a single patient eligible for outpatient therapy [153].

\section{Safety}

\subsection{Adverse Events}

Safety data with lipoglycopeptides are limited to those of published clinical trials and therefore only concern a few hundred patients. Thus, rare adverse effects may have escaped this analysis and could appear after broad-scale use in real-life patient populations. Therefore, based on the currently available literature, the safety profile of these drugs was globally comparable with that of their comparators in published trials (see Table 5). A few adverse events do, however, need to be highlighted and discussed in more detail.

All three drugs can induce hypersensitivity reactions, with cross-allergy possible with vancomycin. Thus, their use should be considered with caution in patients with a history of allergy to vancomycin and the infusion time should be at least $1 \mathrm{~h}$ to avoid red-man syndrome like reactions [131].

The risk of corrected QT (QTc) interval prolongation related to these drugs has been systematically examined in 
Table 5 Adverse drug reactions (in $\%$ of patients) for new lipoglycopeptides as presented in the product information (compiled from clinical trials in patients with acute bacterial skin and skin structure infections $[6,10,14)^{\mathrm{a}}$

\begin{tabular}{|c|c|c|c|c|c|c|}
\hline Adverse reactions & $\begin{array}{l}\text { Oritavancin } \\
(n=976)\end{array}$ & $\begin{array}{l}\text { Vancomycin } \\
(n=983)\end{array}$ & $\begin{array}{l}\text { Telavancin } \\
(n=929)\end{array}$ & $\begin{array}{l}\text { Vancomycin } \\
(n=938)\end{array}$ & $\begin{array}{l}\text { Dalbavancin } \\
(n=1778)\end{array}$ & $\begin{array}{l}\text { Vancomycin } \\
(n=1224)\end{array}$ \\
\hline \multicolumn{7}{|l|}{ Body as a whole } \\
\hline Rigors & & & 4 & 2 & & \\
\hline \multicolumn{7}{|l|}{ Gastrointestinal disorders } \\
\hline Diarrhea & 3.7 & 3.4 & 7 & 8 & 4.4 & 5.9 \\
\hline Nausea & 9.9 & 10.5 & 27 & 15 & 5.5 & 6.4 \\
\hline Vomiting & 4.6 & 4.7 & 14 & 7 & 2.8 & 3.0 \\
\hline $\begin{array}{l}\text { Others: gastrointestinal hemorrhage, melena, } \\
\text { hematochezia, abdominal pain }\end{array}$ & & & & & $<2$ & \\
\hline \multicolumn{7}{|l|}{ Nervous system disorders } \\
\hline Dizziness & 2.7 & 2.6 & 6 & 6 & & \\
\hline Headache & 7.1 & 6.7 & & & & \\
\hline Taste disturbance & & & 33 & 7 & & \\
\hline \multicolumn{7}{|l|}{ General disorders and administration } \\
\hline Infusion-related reaction & & & & & $<2$ & \\
\hline Infusion-site phlebitis & 2.5 & 1.5 & & & & \\
\hline Infusion-site reaction & 1.9 & 3.5 & 4 & 4 & & \\
\hline $\begin{array}{l}\text { Others: infusion-site erythema, extravasation, } \\
\text { induration, edema peripheral }\end{array}$ & $<1$ & & & & & \\
\hline \multicolumn{7}{|l|}{ Immune system disorders } \\
\hline Hypersensitivity & $<1$ & & & & & \\
\hline \multicolumn{7}{|l|}{ Musculoskeletal and connective tissue disorders } \\
\hline Tenosynovitis & $<1$ & & & & & \\
\hline Myalgia & $<1$ & & & & & \\
\hline \multicolumn{7}{|l|}{ Skin and subcutaneous tissue disorders } \\
\hline Pruritis & $<1$ & & 6 & 13 & 2.1 & 3.3 \\
\hline Rash & $<1$ & & & & 2.7 & 2.4 \\
\hline $\begin{array}{l}\text { Others: urticaria, angioedema, erythema } \\
\text { multiforme, leukocytoclastic vasculitis }\end{array}$ & $<1$ & & & & & \\
\hline \multicolumn{7}{|l|}{ Infections and infestations } \\
\hline Abscess (limb and subcutaneous) & 3.8 & 2.3 & & & & \\
\hline Osteomyelitis & $<1$ & & & & & \\
\hline \multicolumn{7}{|l|}{ Respiratory, thoracic, and mediastinal disorders } \\
\hline Bronchospasm, wheezing & $<1$ & & & & & \\
\hline \multicolumn{7}{|l|}{ Metabolism and nutrition disorders } \\
\hline Hypoglycemia & $<1$ & & & & & \\
\hline Decreased appetite & & & 3 & 2 & & \\
\hline \multicolumn{7}{|l|}{ Renal system } \\
\hline Foamy urine & & & 13 & 3 & & \\
\hline Renal impairment & & & 3 & 1 & & \\
\hline \multicolumn{7}{|l|}{ Hepatobiliary disorders } \\
\hline Hepatotoxicity & & & & & $<2$ & \\
\hline \multicolumn{7}{|l|}{ Blood and lymphatic system disorders } \\
\hline Anemia & $<1$ & & & & $<2$ & \\
\hline Eosinophilia & $<1$ & & & & $<2$ & \\
\hline $\begin{array}{l}\text { Others: hemorrhagic anemia, leucopenia, } \\
\text { neutropenia, thrombocytopenia, thrombocytosis, } \\
\text { petechiae }\end{array}$ & & & & & $<2$ & \\
\hline Investigations & & & & & & \\
\hline
\end{tabular}


Table 5 continued

\begin{tabular}{|c|c|c|c|c|c|c|}
\hline Adverse reactions & $\begin{array}{l}\text { Oritavancin } \\
(n=976)\end{array}$ & $\begin{array}{l}\text { Vancomycin } \\
(n=983)\end{array}$ & $\begin{array}{l}\text { Telavancin } \\
(n=929)\end{array}$ & $\begin{array}{l}\text { Vancomycin } \\
(n=938)\end{array}$ & $\begin{array}{l}\text { Dalbavancin } \\
(n=1778)\end{array}$ & $\begin{array}{l}\text { Vancomycin } \\
(n=1224)\end{array}$ \\
\hline Alanine aminotransferase increased & 2.8 & 1.5 & & & 0.8 & 0.2 \\
\hline Aspartate aminotransferase increased & 1.8 & 1.5 & & & & \\
\hline Total bilirubin increased & $<1$ & & & & & \\
\hline Hyperuricemia & $<1$ & & & & & \\
\hline Increase in serum creatinine (1.5-fold) & & & 15 & 7 & & \\
\hline \multicolumn{7}{|l|}{ Cardiac disorders } \\
\hline Tachycardia & 2.5 & 1.1 & & & & \\
\hline
\end{tabular}

a Vancomycin data are presented on the right of each new glycopeptide for the corresponding trial

healthy volunteers, with negative results reported for oritavancin $800 \mathrm{mg}$ [4] or 1.3-fold the clinical dose of $1200 \mathrm{mg}$ [6], telavancin 7.5-15 mg/kg [154], and dalbavancin $1500 \mathrm{mg}$ [155]. In patients from phase III trials, however, $1.5 \%$ of those patients treated with telavancin for skin infections (vs. $0.6 \%$ of vancomycin-treated patients) and $8 \%$ of those treated for pneumonia (vs. $7 \%$ with vancomycin) experienced QTc interval prolongation of $>60 \mathrm{~ms}$ or a QTc interval $>500 \mathrm{~ms}$, the risk being higher when coadministered with drugs known to prolong the QTc interval or to induce torsades de pointes [10, 140, 156].

For oritavancin, two adverse reactions were more frequent than in the comparator-treated population [157]. First, oritavancin-treated patients were at higher risk of developing osteomyelitis (five cases vs. zero for vancomycin in the SOLO 2 study [158]). These events occurred within 1-9 days after study drug initiation, suggesting that the osteomyelitis may have been pre-existing at the time of study entry. Likewise, elevation of transaminases was more frequent in oritavancin-treated patients in SOLO 1, but it was transient and not reported as serious or as being associated with adverse symptoms related to liver function [159]. Reversible elevation in serum levels of hepatic enzymes was also reported for dalbavancin, especially in patients with underlying conditions affecting liver enzymes such as chronic viral hepatitis of alcohol abuse [14].

With respect to telavancin, two other adverse events of potential concern were evidenced in clinical trials. First, telavancin induces taste disturbance, described as a soapy or metallic taste, in one-third of patients [131]. Second, signs of renal toxicity have been evidenced such as an increase in serum creatinine and foamy urine. However, the latter effect does not necessarily reflect toxicity and could also possibly be due to the renal elimination of hydroxypropyl- $\beta$-cyclodextrin present in the formulation as a solubilizing agent [160]. Telavancin should thus be used with caution in patients predisposed to kidney dysfunction (pre-existing renal disease, diabetes mellitus, congestive heart failure, or hypertension) [10]. Studies in rats suggest that the onset of kidney injury depends on the dose and on the dosing interval (more rapid if a longer dosing interval) [161].

Elevation of hepatic enzymes was more frequently noticed in patients receiving dalbavancin than vancomycin [14]; other adverse effects were comparable.

\subsection{Interference with Laboratory Tests and Drug- Drug Interactions}

Oritavancin [6] and telavancin [162] may interfere in coagulation testing [aPTT (activated partial thromboplastin time) during $48 \mathrm{~h}$ or INR (international normalized ratio) during $24 \mathrm{~h}$ ] because of their capacity to inhibit the activity of phospholipases included in reagents. An anticoagulant that does not need monitoring may therefore be preferable during antibacterial therapy. This effect has not been reported for dalbavancin [14]. Telavancin also interferes with urine qualitative dipstick protein assays, as well as quantitative dye methods [10].

Studies of interactions with hepatic cytochromes have been conducted. Oritavancin appears to be a weak inhibitor of cytochrome P450 (CYP) 2C9 and 2C19 and a weak inducer of CYP3A4 and 2D6 [6]. A significant risk of bleeding has been reported in patients taking warfarin at the same time. No significant metabolism by hepatic cytochromes or drug interactions related to inhibition or induction of metabolism has been described for both telavancin and dalbavancin [10, 14, 163]. Nor was any pharmacokinetic interaction described when co-administering telavancin with different $\beta$-lactam antibacterials [164].

\section{Healthcare Costs}

As vancomycin is now a generic drug, the drug acquisition cost will obviously be much higher with these novel lipoglycopeptides (see Table 6). However, the cost of MRSA 
Table 6 Drug wholesale acquisition cost associated with treatment by new lipoglycopeptides as compared with vancomycin (see Drugs for MRSA skin and soft-tissue infections [183] and references cited therein)

\begin{tabular}{|c|c|c|c|c|}
\hline Antibacterial & 1 vial $(\mathrm{mg})$ & Unit price (\$US) & Whole treatment & Total price (\$US) \\
\hline Vancomycin & 1000 & 9.5 & $2 \times 1000 \mathrm{mg} \times 7-14$ days & $\sim 133-266$ \\
\hline Oritavancin $\left(\right.$ Orbactiv $\left.^{\circledR}\right)$ & 400 & 1160 & $1200 \mathrm{mg}$ & $\sim 2900$ \\
\hline Telavancin (Vibativ $\left.{ }^{\circledR}\right)$ & 750 & 309.5 & $750 \mathrm{mg} \times 7-14$ days & $\sim 2167-4333$ \\
\hline Dalbavancin (Dalvance ${ }^{\circledR}$ ) & 500 & 1490 & $1000+500 \mathrm{mg}$ & $\sim 4470$ \\
\hline
\end{tabular}

infections is only marginally dependent on the price of the administered drug and mainly reflects the healthcare resources needed to treat the infections, more specifically the length of stay in the hospital, which is in general 1.5-3 times greater than for an MSSA infection [165]. When using the reference drug vancomycin, costs associated with therapeutic monitoring, twice-daily injection or continuous infusion, and prolonged treatment duration need to be taken into account. A cost-effectiveness analysis with telavancin concluded that the treatment cost would be similar for patients from the ATLAS studies treated with vancomycin and telavancin if the acquisition cost of telavancin was approximately 15 times higher than that of vancomycin; the cost effectiveness of telavancin was greater if considering MRSA-infected patients only [166]. The simplified therapeutic scheme of oritavancin, and, to a lesser extent, of dalbavancin, appears to be an appealing solution to the economic burden represented by hospitalization, but the impact of such therapies on global treatment costs needs to be established [32].

\section{Conclusion}

The pharmacological profile of oritavancin, telavancin, and, to a lesser extent, dalbavancin, demonstrates clear advantages over that of conventional glycopeptides with respect to their bactericidal character (oritavancin and telavancin), activity against vancomycin-resistant strains (oritavancin), or prolonged residence in the organism (oritavancin and dalbavancin). However, this superiority over conventional glycopeptides was not as clear in their clinical evaluation. This discrepancy may be related to the general non-inferiority design of registration studies, the planning and reporting of which is sometimes reported as being suboptimal for anti-infective agents [167]. Moreover, these studies mainly enrolled patients with mid-severity infections [146, 159, 168], against which the comparator is effective, and thus the advantages of more powerful antibacterials do not show through. Thus, superiority trials should be planned in specific indications or situations [169, 170]. Likewise, additional studies in more severe infections as well as clinical experience in real-life situations will possibly help to document these advantages and position these drugs in our current arsenal. At this stage, one can already point out the possibility of using oritavancin or dalbavancin for outpatient therapy, which could contribute to containing costs, improving quality of life, and adherence to the treatment, as well as to reducing adverse reactions related to prolonged intravenous therapy such as thrombophlebitis or catheterrelated bloodstream infections [32, 130, 134]. On the other hand, their long half-life asks the question of how to manage adverse effects [133], oritavancin being not extracted by dialysis [171] and dalbavancin only by high-flux dialysers [172]. Thus, among these three drugs, and based on current knowledge of their respective safety profile, the clinician's choice should take into account specific safety concerns, such as a possibly increased risk of osteomyelitis with oritavancin, of nephrotoxicity and QTc interval prolongation with telavancin, and of increased hepatic enzymes with dalbavancin. Also, in this context, dalbavancin may show an advantage by presenting a lower potential for drug interactions or interference in laboratory testing than the other two drugs [134]. As a result, further clinical experience is warranted to better position each of these molecules in our current arsenal and to define their potential in difficult-totreat infections in which they could reveal all of their advantages.

Acknowledgments F. Van Bambeke is Maître de Recherches from the Belgian du Fonds de la Recherche Scientifique.

\section{Compliance with Ethical Standards}

Conflicts of Interest F. Van Bambeke received research grants from Targanta Therapeutics (now The Medicines Company), and Theravance for the performance of in vitro work with oritavancin and telavancin, respectively (most of the corresponding references cited in the present paper).

\section{References}

1. Cooper RD, Snyder NJ, Zweifel MJ, et al. Reductive alkylation of glycopeptide antibiotics: synthesis and antibacterial activity. J Antibiot (Tokyo). 1996;49(6):575-81.

2. Allen NE. From vancomycin to oritavancin: the discovery and development of a novel lipoglycopeptide antibiotic. AntiInf $\mathrm{Ag}$ Med Chem. 2010;9:23-47. 
3. Dunbar LM, Milata J, McClure T, et al. Comparison of the efficacy and safety of oritavancin front-loaded dosing regimens to daily dosing: an analysis of the SIMPLIFI trial. Antimicrob Agents Chemother. 2011;55(7):3476-84.

4. Darpo B, Lee SK, Moon TE, et al. Oritavancin, a new lipoglycopeptide antibiotic: results from a thorough QT study. J Clin Pharmacol. 2010;50(8):895-903.

5. Van Bambeke F. Glycopeptides in clinical development: pharmacological profile and clinical perspectives. Curr Opin Pharmacol. 2004;4(5):471-8.

6. The Medicines Company. Orbactiv ${ }^{\mathrm{TM}}$ full prescribing information. http://www.orbactiv.com. Accessed 29 Aug 2015.

7. The Medicines Company. Orbactiv ${ }^{\mathrm{TM}}$ summary of product characteristics. http://www.Ema.Europa.eu/docs/en_GB/document library/EPAR_-_Product_Information/human/003785/WC500186 343.pdf. Accessed 29 Aug 2015.

8. Leadbetter MR, Adams SM, Bazzini B, et al. Hydrophobic vancomycin derivatives with improved ADME properties: discovery of telavancin (TD-6424). J Antibiot (Tokyo). 2004;57(5):326-36.

9. Wenzler E, Rodvold KA. Telavancin: the long and winding road from discovery to Food and Drug Administration approvals and future directions. Clin Infect Dis. 2015;61(Suppl 2):S38-47.

10. Theravance BioPharma. Vibativ ${ }^{\mathrm{TM}}$ full prescribing information. http://www.vibativ.com. Accessed 29 Aug 2015.

11. Clinigen Healthcare Ltd. Vibativ ${ }^{\mathrm{TM}}$ summary of product characteristics. http://www.ema.Europa.eu/docs/en_GB/document_library/ EPAR_-_Product_Information/human/001240/WC500115364.pdf. Accessed 29 Aug 2015.

12. Malabarba A, Ciabatti R, Kettenring J, et al. Amides of deacetylglucosaminyl-deoxy teicoplanin active against highly glycopeptide-resistant enterococci. Synthesis and antibacterial activity. J Antibiot (Tokyo). 1994;47(12):1493-506.

13. Malabarba A, Ciabatti R, Scotti R, et al. New semisynthetic glycopeptides MDL 63,246 and MDL 63,042, and other amide derivatives of antibiotic A-40,926 active against highly glycopeptide-resistant VanA enterococci. J Antibiot (Tokyo). 1995;48(8):869-83.

14. Durata Therapeutics. Dalvance ${ }^{\mathrm{TM}}$ full prescribing information. http://www.dalvance.com. Accessed 29 Aug 2015.

15. Durata Therapeutics, Durata. Xydalba ${ }^{\mathrm{TM}}$ summary of product characteristics. http://www.ema.europa.eu/docs/en_GB/document_ library/EPAR_-_Product_Information/human/002840/WC5001838 69.pdf. Accessed 29 Aug 2015.

16. Butler MS, Hansford KA, Blaskovich MAT, et al. Glycopeptide antibiotics: back to the future. J Antibiot (Tokyo). 2014;67(9): 631-44.

17. Barna JC, Williams DH. The structure and mode of action of glycopeptide antibiotics of the vancomycin group. Annu Rev Microbiol. 1984;38:339-57.

18. Reynolds PE. Structure, biochemistry and mechanism of action of glycopeptide antibiotics. Eur J Clin Microbiol Infect Dis. 1989;8(11):943-50.

19. Lamp KC, Rybak MJ, Bailey EM, et al. In vitro pharmacodynamic effects of concentration, $\mathrm{pH}$, and growth phase on serum bactericidal activities of daptomycin and vancomycin. Antimicrob Agents Chemother. 1992;36(12):2709-14.

20. Hiramatsu K, Hanaki H, Ino T, et al. Methicillin-resistant Staphylococcus aureus clinical strain with reduced vancomycin susceptibility. J Antimicrob Chemother. 1997;40(1):135-6.

21. Gardete S, Tomasz A. Mechanisms of vancomycin resistance in Staphylococcus aureus. J Clin Invest. 2014;124(7):2836-40.

22. Courvalin P. Vancomycin resistance in gram-positive cocci. Clin Infect Dis. 2006;42(Suppl 1):S25-34.

23. Gould IM. Treatment of bacteraemia: methicillin-resistant Staphylococcus aureus (MRSA) to vancomycin-resistant S. aureus (VRSA). Int J Antimicrob Agents. 2013;42(Suppl):S17-21.
24. Beauregard DA, Williams DH, Gwynn MN, et al. Dimerization and membrane anchors in extracellular targeting of vancomycin group antibiotics. Antimicrob Agents Chemother. 1995;39(3): 781-5.

25. Van Bambeke F, Van Laethem Y, Courvalin P, et al. Glycopeptide antibiotics: from conventional molecules to new derivatives. Drugs. 2004;64(9):913-36.

26. Allen NE, Nicas TI. Mechanism of action of oritavancin and related glycopeptide antibiotics. FEMS Microbiol Rev. 2003;26(5):511-32.

27. Cheng M, Ziora ZM, Hansford KA, et al. Anti-cooperative ligand binding and dimerisation in the glycopeptide antibiotic dalbavancin. Org Biomol Chem. 2014;12(16):2568-75.

28. Economou NJ, Nahoum V, Weeks SD, et al. A carrier protein strategy yields the structure of dalbavancin. J Am Chem Soc. 2012;134(10):4637-45.

29. Belley A, McKay GA, Arhin FF, et al. Oritavancin disrupts membrane integrity of Staphylococcus aureus and vancomycinresistant enterococci to effect rapid bacterial killing. Antimicrob Agents Chemother. 2010;54(12):5369-71.

30. Higgins DL, Chang R, Debabov DV, et al. Telavancin, a multifunctional lipoglycopeptide, disrupts both cell wall synthesis and cell membrane integrity in methicillin-resistant Staphylococcus aureus. Antimicrob Agents Chemother. 2005;49(3): 1127-34.

31. Belley A, Harris R, Beveridge T, et al. Ultrastructural effects of oritavancin on methicillin-resistant Staphylococcus aureus and vancomycin-resistant Enterococcus. Antimicrob Agents Chemother. 2009;53(2):800-4.

32. Messina JA, Fowler VGJ, Corey GR. Oritavancin for acute bacterial skin and skin structure infections. Expert Opin Pharmacother. 2015;16(7):1091-8.

33. Lunde CS, Hartouni SR, Janc JW, et al. Telavancin disrupts the functional integrity of the bacterial membrane through targeted interaction with the cell wall precursor lipid II. Antimicrob Agents Chemother. 2009;53(8):3375-83.

34. Song Y, Lunde CS, Benton BM, et al. Further insights into the mode of action of the lipoglycopeptide telavancin through global gene expression studies. Antimicrob Agents Chemother. 2012;56(6):3157-64.

35. Barcia-Macay M, Lemaire S, Mingeot-Leclercq MP, et al. Evaluation of the extracellular and intracellular activities (human THP-1 macrophages) of telavancin versus vancomycin against methicillin-susceptible, methicillin-resistant, vancomycin-intermediate and vancomycin-resistant Staphylococcus aureus. J Antimicrob Chemother. 2006;58(6): 1177-84.

36. Domenech O, Dufrene YF, Van Bambeke F, et al. Interactions of oritavancin, a new semi-synthetic lipoglycopeptide, with lipids extracted from Staphylococcus aureus. Biochim Biophys Acta. 2010;1798(10):1876-85.

37. Munch D, Engels I, Muller A, et al. Structural variations of the cell wall precursor lipid II - influence on binding and activity of the lipoglycopeptide antibiotic oritavancin. Antimicrob Agents Chemother. 2015;59(2):772-81.

38. Kim SJ, Cegelski L, Stueber D, et al. Oritavancin exhibits dual mode of action to inhibit cell-wall biosynthesis in Staphylococcus aureus. J Mol Biol. 2008;377(1):281-93.

39. Patti GJ, Kim SJ, Yu TY, et al. Vancomycin and oritavancin have different modes of action in Enterococcus faecium. J Mol Biol. 2009;392(5):1178-91.

40. Mendes RE, Farrell DJ, Sader HS, et al. Baseline activity of telavancin against Gram-positive clinical isolates responsible for documented infections in US hospitals (2011-2012) as determined by the revised susceptibility testing method. Antimicrob Agents Chemother. 2015;59(1):702-6. 
41. Arhin FF, Sarmiento I, Belley A, et al. Effect of polysorbate 80 on oritavancin binding to plastic surfaces: implications for susceptibility testing. Antimicrob Agents Chemother. 2008; 52(5):1597-603.

42. Rennie RP, Koeth L, Jones RN, et al. Factors influencing broth microdilution antimicrobial susceptibility test results for dalbavancin, a new glycopeptide agent. J Clin Microbiol. 2007; 45(10):3151-4.

43. Clinical and Laboratory Standards Institute. Performance standards for antimicrobial susceptibility testing. In: 25th informational supplement (MS100-S25). Wayne: Clinical and Laboratory Standard Institute; 2015.

44. Arhin FF, Draghi DC, Pillar CM, et al. Correlation between oritavancin and vancomycin minimum inhibitory concentrations in staphylococci. Int J Antimicrob Agents. 2012;40(6):562-3.

45. Jones RN, Turnidge JD, Moeck G, et al. Use of in vitro vancomycin testing results to predict susceptibility to oritavancin, a new long-acting lipoglycopeptide. Antimicrob Agents Chemother. 2015;59(4):2405-9.

46. Jones RN, Farrell DJ, Flamm RK, et al. Surrogate analysis of vancomycin to predict susceptible categorization of dalbavancin. Diagn Microbiol Infect Dis. 2015;82(1):73-7.

47. Saravolatz LD, Pawlak J, Johnson LB. In vitro activity of oritavancin against community-associated methicillin-resistant Staphylococcus aureus (CA-MRSA), vancomycin-intermediate $S$. aureus (VISA), vancomycin-resistant S. aureus (VRSA) and daptomycin-non-susceptible $S$. aureus (DNSSA). Int J Antimicrob Agents. 2010;36(1):69-72.

48. Hill CM, Krause KM, Lewis SR, et al. Specificity of induction of the vanA and $\operatorname{van} B$ operons in vancomycin-resistant enterococci by telavancin. Antimicrob Agents Chemother. 2010;54(7): 2814-8.

49. Streit JM, Sader HS, Fritsche TR, et al. Dalbavancin activity against selected populations of antimicrobial-resistant Grampositive pathogens. Diagn Microbiol Infect Dis. 2005;53(4): 307-10.

50. Karlowsky JA, Walkty AJ, Baxter MR, et al. In vitro activity of oritavancin against Gram-positive pathogens isolated in Canadian hospital laboratories from 2011 to 2013. Diagn Microbiol Infect Dis. 2014;80(4):311-5.

51. Citron DM, Tyrrell KL, Goldstein EJC. Comparative in vitro activities of dalbavancin and seven comparator agents against 41 Staphylococcus species cultured from osteomyelitis infections and 18 VISA and hVISA strains. Diagn Microbiol Infect Dis. 2014;79(4):438-40.

52. Biavasco F, Vignaroli C, Lupidi R, et al. In vitro antibacterial activity of LY333328, a new semisynthetic glycopeptide. Antimicrob Agents Chemother. 1997;41(10):2165-72.

53. O'Connor R, Baines SD, Freeman J, et al. In vitro susceptibility of genotypically distinct and clonal Clostridium difficile strains to oritavancin. J Antimicrob Chemother. 2008;62(4):762-5.

54. Goldstein EJC, Citron DM, Tyrrell KL, et al. Bactericidal activity of telavancin, vancomycin and metronidazole against Clostridium difficile. Anaerobe. 2010;16(3):220-2.

55. Goldstein EJC, Citron DM, Merriam CV, et al. In vitro activities of dalbavancin and nine comparator agents against anaerobic gram-positive species and corynebacteria. Antimicrob Agents Chemother. 2003;47(6):1968-71.

56. Chilton $\mathrm{CH}$, Freeman J, Crowther GS, et al. Effectiveness of a short (4 day) course of oritavancin in the treatment of simulated Clostridium difficile infection using a human gut model. J Antimicrob Chemother. 2012;67(10):2434-7.

57. Freeman J, Marquis M, Crowther GS, et al. Oritavancin does not induce Clostridium difficile germination and toxin production in hamsters or a human gut model. J Antimicrob Chemother. 2012;67(12):2919-26.
58. Chilton CH, Freeman J, Baines SD, et al. Evaluation of the effect of oritavancin on Clostridium difficile spore germination, outgrowth and recovery. J Antimicrob Chemother. 2013;68(9):2078-82.

59. Arthur M, Depardieu F, Reynolds P, et al. Moderate-level resistance to glycopeptide LY333328 mediated by genes of the $v a n A$ and $v a n B$ clusters in enterococci. Antimicrob Agents Chemother. 1999;43(8):1875-80.

60. Song Y, Lunde CS, Benton BM, et al. Studies on the mechanism of telavancin decreased susceptibility in a laboratory-derived mutant. Microb Drug Resist. 2013;19(4):247-55.

61. Scherr TD, Heim CE, Morrison JM, et al. Hiding in plain sight: interplay between Staphylococcal biofilms and host immunity. Front Immunol. 2014;5:37.

62. Garzoni C, Kelley WL. Staphylococcus aureus: new evidence for intracellular persistence. Trends Microbiol. 2009;17(2):5965.

63. Belley A, Neesham-Grenon E, McKay G, et al. Oritavancin kills stationary-phase and biofilm Staphylococcus aureus cells in vitro. Antimicrob Agents Chemother. 2009;53(3):918-25.

64. Smith K, Gemmell CG, Lang S. Telavancin shows superior activity to vancomycin with multidrug-resistant Staphylococcus aureus in a range of in vitro biofilm models. Eur J Clin Microbiol Infect Dis. 2013;32(10):1327-32.

65. Gander S, Kinnaird A, Finch R. Telavancin: in vitro activity against staphylococci in a biofilm model. J Antimicrob Chemother. 2005;56(2):337-43.

66. LaPlante KL, Mermel LA. In vitro activities of telavancin and vancomycin against biofilm-producing Staphylococcus aureus, S. epidermidis, and Enterococcus faecalis strains. Antimicrob Agents Chemother. 2009;53(7):3166-9.

67. Chan C, Hardin TC, Smart JI. A review of telavancin activity in in vitro biofilms and animal models of biofilm-associated infections. Future Microbiol. 2015;1-14.

68. Barcia-Macay M, Seral C, Mingeot-Leclercq MP, et al. Pharmacodynamic evaluation of the intracellular activities of antibiotics against Staphylococcus aureus in a model of THP-1 macrophages. Antimicrob Agents Chemother. 2006;50(3):84151.

69. Seral C, Van Bambeke F, Tulkens PM. Quantitative analysis of gentamicin, azithromycin, telithromycin, ciprofloxacin, moxifloxacin, and oritavancin (LY333328) activities against intracellular Staphylococcus aureus in mouse J774 macrophages. Antimicrob Agents Chemother. 2003;47(7):2283-92.

70. Lemaire S, Kosowska-Shick K, Julian K, et al. Activities of antistaphylococcal antibiotics towards the extracellular and intraphagocytic forms of Staphylococcus aureus isolates from a patient with persistent bacteraemia and endocarditis. Clin Microbiol Infect. 2008;14(8):766-77.

71. Garcia LG, Lemaire S, Kahl BC, et al. Influence of the protein kinase $\mathrm{C}$ activator phorbol myristate acetate on the intracellular activity of antibiotics against hemin- and menadione-auxotrophic small-colony variant mutants of Staphylococcus aureus and their wild-type parental strain in human THP-1 cells. Antimicrob Agents Chemother. 2012;56(12):6166-74.

72. Garcia LG, Lemaire S, Kahl BC, et al. Pharmacodynamic evaluation of the activity of antibiotics against hemin- and menadione-dependent small-colony variants of Staphylococcus aureus in models of extracellular (broth) and intracellular (THP1 monocytes) infections. Antimicrob Agents Chemother. 2012;56(7):3700-11.

73. Nguyen HA, Denis O, Vergison A, et al. Intracellular activity of antibiotics in a model of human THP-1 macrophages infected by a Staphylococcus aureus small-colony variant strain isolated from a cystic fibrosis patient: pharmacodynamic evaluation and comparison with isogenic normal-phenotype and revertant strains. Antimicrob Agents Chemother. 2009;53(4):1434-42. 
74. Nguyen HA, Denis O, Vergison A, et al. Intracellular activity of antibiotics in a model of human THP-1 macrophages infected by a Staphylococcus aureus small-colony variant strain isolated from a cystic fibrosis patient: study of antibiotic combinations. Antimicrob Agents Chemother. 2009;53(4):1443-9.

75. Van Bambeke F, Carryn S, Seral C, et al. Cellular pharmacokinetics and pharmacodynamics of the glycopeptide antibiotic oritavancin (LY333328) in a model of J774 mouse macrophages. Antimicrob Agents Chemother. 2004;48(8):2853-60.

76. Van Bambeke F, Saffran J, Mingeot-Leclercq MP, et al. Mixedlipid storage disorder induced in macrophages and fibroblasts by oritavancin (LY333328), a new glycopeptide antibiotic with exceptional cellular accumulation. Antimicrob Agents Chemother. 2005;49(5):1695-700.

77. Lemaire S, Mingeot-Leclercq MP, Tulkens PM, et al. Study of macrophage functions in murine $\mathrm{J} 774$ cells and human activated THP-1 cells exposed to oritavancin, a lipoglycopeptide with high cellular accumulation. Antimicrob Agents Chemother. 2014;58(4):2059-66.

78. Baquir B, Lemaire S, Van Bambeke F, et al. Macrophage killing of bacterial and fungal pathogens is not inhibited by intense intracellular accumulation of the lipoglycopeptide antibiotic oritavancin. Clin Infect Dis. 2012;54(Suppl 3):S229-32.

79. Barcia-Macay M, Mouaden F, Mingeot-Leclercq MP, et al. Cellular pharmacokinetics of telavancin, a novel lipoglycopeptide antibiotic, and analysis of lysosomal changes in cultured eukaryotic cells (J774 mouse macrophages and rat embryonic fibroblasts). J Antimicrob Chemother. 2008;61(6):1288-94.

80. Arhin FF, McKay GA, Beaulieu S, et al. Time-kill kinetics of oritavancin and comparator agents against Streptococcus pyogenes. Int J Antimicrob Agents. 2009;34(6):550-4.

81. McKay GA, Beaulieu S, Arhin FF, et al. Time-kill kinetics of oritavancin and comparator agents against Staphylococcus aureus, Enterococcus faecalis and Enterococcus faecium. J Antimicrob Chemother. 2009;63(6):1191-9.

82. Vidaillac C, Parra-Ruiz J, Rybak MJ. In vitro time-kill analysis of oritavancin against clinical isolates of methicillin-resistant Staphylococcus aureus with reduced susceptibility to daptomycin. Diagn Microbiol Infect Dis. 2011;71(4):470-3.

83. Coyle EA, Rybak MJ. Activity of oritavancin (LY333328), an investigational glycopeptide, compared to that of vancomycin against multidrug-resistant Streptococcus pneumoniae in an in vitro pharmacodynamic model. Antimicrob Agents Chemother. 2001;45(3):706-9.

84. Arhin FF, Sarmiento I, Parr TRJ, et al. Activity of oritavancin and comparators in vitro against standard and high inocula of Staphylococcus aureus. Int J Antimicrob Agents. 2012;39(2): 159-62.

85. Arhin FF, Sarmiento I, Moeck G. Oritavancin retains bactericidal activity in vitro against standard and high inocula of heterogeneous vancomycin-intermediate Staphylococcus aureus (hVISA). Int J Antimicrob Agents. 2013;41(4):397-8.

86. Lin G, Pankuch GA, Appelbaum PC, et al. Activity of telavancin compared to other agents against coagulase-negative staphylococci with different resistotypes by time kill. Diagn Microbiol Infect Dis. 2012;73(3):287-9.

87. Leonard SN, Szeto YG, Zolotarev M, et al. Comparative in vitro activity of telavancin, vancomycin and linezolid against heterogeneously vancomycin-intermediate Staphylococcus aureus (hVISA). Int J Antimicrob Agents. 2011;37(6):558-61.

88. Smith JR, Barber KE, Hallesy J, et al. Telavancin demonstrates activity against methicillin-resistant Staphylococcus aureus with reduced susceptibility to vancomycin, daptomycin, and linezolid via broth microdilution minimum inhibitory concentration and one-compartment pharmacokinetic/pharmacodynamic modeling. Antimicrob Agents Chemother. 2015;59(9):5529-34.
89. Goldstein BP, Draghi DC, Sheehan DJ, et al. Bactericidal activity and resistance development profiling of dalbavancin. Antimicrob Agents Chemother. 2007;51(4):1150-4.

90. Baltch AL, Smith RP, Ritz WJ, et al. Comparison of inhibitory and bactericidal activities and postantibiotic effects of LY333328 and ampicillin used singly and in combination against vancomycin-resistant Enterococcus faecium. Antimicrob Agents Chemother. 1998;42(10):2564-8 .

91. Mercier RC, Houlihan HH, Rybak MJ. Pharmacodynamic evaluation of a new glycopeptide, LY333328, and in vitro activity against Staphylococcus aureus and Enterococcus faecium. Antimicrob Agents Chemother. 1997;41(6):1307-12.

92. Zelenitsky SA, Booker B, Laing N, et al. Synergy of an investigational glycopeptide, LY333328, with once-daily gentamicin against vancomycin-resistant Enterococcus faecium in a multiple-dose, in vitro pharmacodynamic model. Antimicrob Agents Chemother. 1999;43(3):592-7.

93. Lin G, Pankuch G, Appelbaum PC, et al. Antistaphylococcal activity of oritavancin and its synergistic effect in combination with other antimicrobial agents. Antimicrob Agents Chemother. 2014;58(10):6251-4.

94. Leonard SN, Supple ME, Gandhi RG, et al. Comparative activities of telavancin combined with nafcillin, imipenem, and gentamicin against Staphylococcus aureus. Antimicrob Agents Chemother. 2013;57(6):2678-83.

95. Lin G, Pankuch GA, Ednie LM, et al. Antistaphylococcal activities of telavancin tested alone and in combination by time-kill assay. Antimicrob Agents Chemother. 2010;54(5): 2201-5.

96. Johnson DM, Fritsche TR, Sader HS, et al. Evaluation of dalbavancin in combination with nine antimicrobial agents to detect enhanced or antagonistic interactions. Int J Antimicrob Agents. 2006;27(6):557-60.

97. Ambrose PG, Drusano GL, Craig WA. In vivo activity of oritavancin in animal infection models and rationale for a new dosing regimen in humans. Clin Infect Dis. 2012;54(Suppl 3):S220-8.

98. Kaatz GW, Seo SM, Aeschlimann JR, et al. Efficacy of LY333328 against experimental methicillin-resistant Staphylococcus aureus endocarditis. Antimicrob Agents Chemother. 1998;42(4):981-3.

99. Saleh-Mghir A, Lefort A, Petegnief Y, et al. Activity and diffusion of LY333328 in experimental endocarditis due to vancomycin-resistant Enterococcus faecalis. Antimicrob Agents Chemother. 1999;43(1):115-20.

100. Rupp ME, Fey PD, Longo GM. Effect of LY333328 against vancomycin-resistant Enterococcus faecium in a rat central venous catheter-associated infection model. J Antimicrob Chemother. 2001;47(5):705-7.

101. Gerber J, Smirnov A, Wellmer A, et al. Activity of LY333328 in experimental meningitis caused by a Streptococcus pneumoniae strain susceptible to penicillin. Antimicrob Agents Chemother. 2001;45(7):2169-72.

102. Cabellos C, Fernandez A, Maiques JM, et al. Experimental study of LY333328 (oritavancin), alone and in combination, in therapy of cephalosporin-resistant pneumococcal meningitis. Antimicrob Agents Chemother. 2003;47(6):1907-11.

103. Heine HS, Bassett J, Miller L, et al. Efficacy of oritavancin in a murine model of Bacillus anthracis spore inhalation anthrax. Antimicrob Agents Chemother. 2008;52(9):3350-7.

104. Hegde SS, Janc JW. Efficacy of telavancin, a lipoglycopeptide antibiotic, in experimental models of Gram-positive infection. Expert Rev Anti Infect Ther. 2014;12(12):1463-75.

105. Reyes N, Skinner R, Kaniga K, et al. Efficacy of telavancin (TD6424), a rapidly bactericidal lipoglycopeptide with multiple mechanisms of action, in a murine model of pneumonia induced 
by methicillin-resistant Staphylococcus aureus. Antimicrob Agents Chemother. 2005;49(10):4344-6.

106. Reyes N, Skinner R, Benton BM, et al. Efficacy of telavancin in a murine model of bacteraemia induced by methicillin-resistant Staphylococcus aureus. J Antimicrob Chemother. 2006;58(2): 462-5.

107. Xiong YQ, Hady WA, Bayer AS, et al. Telavancin in therapy of experimental aortic valve endocarditis in rabbits due to daptomycin-nonsusceptible methicillin-resistant Staphylococcus aureus. Antimicrob Agents Chemother. 2012;56(11):5528-33.

108. Madrigal AG, Basuino L, Chambers HF. Efficacy of telavancin in a rabbit model of aortic valve endocarditis due to methicillinresistant Staphylococcus aureus or vancomycin-intermediate Staphylococcus aureus. Antimicrob Agents Chemother. 2005; 49(8):3163-5.

109. Miro JM, Garcia-de-la-Maria C, Armero Y, et al. Efficacy of telavancin in the treatment of experimental endocarditis due to glycopeptide-intermediate Staphylococcus aureus. Antimicrob Agents Chemother. 2007;51(7):2373-7.

110. Crandon JL, Kuti JL, Nicolau DP. Comparative efficacies of human simulated exposures of telavancin and vancomycin against methicillin-resistant Staphylococcus aureus with a range of vancomycin MICs in a murine pneumonia model. Antimicrob Agents Chemother. 2010;54(12):5115-9.

111. Stucki A, Gerber P, Acosta F, et al. Efficacy of telavancin against penicillin-resistant pneumococci and Staphylococcus aureus in a rabbit meningitis model and determination of kinetic parameters. Antimicrob Agents Chemother. 2006;50(2):770-3.

112. Yin LY, Calhoun JH, Thomas TS, et al. Efficacy of telavancin in the treatment of methicillin-resistant Staphylococcus aureus osteomyelitis: studies with a rabbit model. J Antimicrob Chemother. 2009;63(2):357-60.

113. Jabes D, Candiani G, Romano G, et al. Efficacy of dalbavancin against methicillin-resistant Staphylococcus aureus in the rat granuloma pouch infection model. Antimicrob Agents Chemother. 2004;48(4):1118-23.

114. Andes D, Craig WA. In vivo pharmacodynamic activity of the glycopeptide dalbavancin. Antimicrob Agents Chemother. 2007;51(5):1633-42.

115. Lefort A, Pavie J, Garry L, et al. Activities of dalbavancin in vitro and in a rabbit model of experimental endocarditis due to Staphylococcus aureus with or without reduced susceptibility to vancomycin and teicoplanin. Antimicrob Agents Chemother. 2004;48(3):1061-4.

116. Baldoni D, Furustrand Tafin U, Aeppli S, et al. Activity of dalbavancin, alone and in combination with rifampicin, against meticillin-resistant Staphylococcus aureus in a foreign-body infection model. Int J Antimicrob Agents. 2013;42(3):220-5.

117. Heine HS, Purcell BK, Bassett J, et al. Activity of dalbavancin against Bacillus anthracis in vitro and in a mouse inhalation anthrax model. Antimicrob Agents Chemother. 2010;54(3): 991-6.

118. Hegde SS, Reyes N, Wiens T, et al. Pharmacodynamics of telavancin (TD-6424), a novel bactericidal agent, against grampositive bacteria. Antimicrob Agents Chemother. 2004;48(8): 3043-50.

119. Boylan CJ, Campanale K, Iversen PW, et al. Pharmacodynamics of oritavancin (LY333328) in a neutropenic-mouse thigh model of Staphylococcus aureus infection. Antimicrob Agents Chemother. 2003;47(5):1700-6.

120. Rubino CM, Bhavnani SM, Moeck G, et al. Population pharmacokinetic analysis for a single 1,200-milligram dose of oritavancin using data from two pivotal phase 3 clinical trials. Antimicrob Agents Chemother. 2015;59(6):3365-72.

121. Belley A, Arhin FF, Sarmiento I, et al. Pharmacodynamics of a simulated single 1,200-milligram dose of oritavancin in an in vitro pharmacokinetic/pharmacodynamic model of methicillin-resistant Staphylococcus aureus infection. Antimicrob Agents Chemother. 2013;57(1):205-11.

122. Lodise TP, Butterfield JM, Hegde SS, et al. Telavancin pharmacokinetics and pharmacodynamics in patients with complicated skin and skin structure infections and various degrees of renal function. Antimicrob Agents Chemother. 2012;56(4): 2062-6.

123. Farkas A. Successful target attainment of telavancin at elevated MICs: fact or fiction? Antimicrob Agents Chemother. 2012;56(8):4560-2.

124. Dowell JA, Goldstein BP, Buckwalter M, et al. Pharmacokinetic-pharmacodynamic modeling of dalbavancin, a novel glycopeptide antibiotic. J Clin Pharmacol. 2008;48(9):1063-8.

125. Dunne MW, Puttagunta S, Sprenger CR, et al. Extended-duration dosing and distribution of dalbavancin into bone and articular tissue. Antimicrob Agents Chemother. 2015;59(4): 1849-55.

126. Goldberg MR, Wong SL, Shaw JP, et al. Lack of effect of moderate hepatic impairment on the pharmacokinetics of telavancin. Pharmacotherapy. 2010;30(1):35-42.

127. Bradley JS, Puttagunta S, Rubino CM, et al. Pharmacokinetics, safety and tolerability of single dose dalbavancin in children 12-17 years of age. Pediatr Infect Dis J. 2015;34(7):748-52.

128. The Medicines Company. Open-label, dose-finding, pharmacokinetics, safety and tolerability study of oritavancin in pediatric patients with suspected or confirmed bacterial infections [ClinicalTrials.gov identifier NCT02134301]. US National Institutes of Health, ClinicalTrials.gov. https://www.clinical trials.gov. Accessed 8 Nov 2015.

129. Theravance Biopharma Antibiotics, Inc. An open-label study of the pharmacokinetics of a single dose of telavancin in pediatric subjects aged 1 to 17 years [ClinicalTrials.gov identifier NCT02013141]. US National Institutes of Health, ClinicalTrials.gov. https://www.clinicaltrials.gov. Accessed 8 Nov 2015.

130. Mitra S, Saeed U, Havlichek DH, et al. Profile of oritavancin and its potential in the treatment of acute bacterial skin structure infections. Infect Drug Resist. 2015;8:189-97.

131. Barriere SL. ATLAS trials: efficacy and safety of telavancin compared with vancomycin for the treatment of skin infections. Future Microbiol. 2010;5(12):1765-73.

132. Barriere SL. The ATTAIN trials: efficacy and safety of telavancin compared with vancomycin for the treatment of hospitalacquired and ventilator-associated bacterial pneumonia. Future Microbiol. 2014;9(3):281-9.

133. Ramdeen S, Boucher HW. Dalbavancin for the treatment of acute bacterial skin and skin structure infections. Expert Opin Pharmacother. 2015;16(13):2073-81.

134. Scott LJ. Dalbavancin: a review in acute bacterial skin and skin structure infections. Drugs. 2015;75(11):1281-91.

135. Pushkin R, Barriere SL, Wang W, et al. Telavancin for Acute Bacterial Skin and Skin Structure Infections (ABSSSI) - a posthoc analysis of the phase 3 ATLAS trials in consideration of the final (2013) FDA guidance. Antimicrob Agents Chemother. 2015;59(10):6170-4.

136. Seltzer E, Dorr MB, Goldstein BP, et al. Once-weekly dalbavancin versus standard-of-care antimicrobial regimens for treatment of skin and soft-tissue infections. Clin Infect Dis. 2003;37(10):1298-303.

137. Stryjewski ME, Chu VH, O'Riordan WD, et al. Telavancin versus standard therapy for treatment of complicated skin and skin structure infections caused by gram-positive bacteria: FAST 2 study. Antimicrob Agents Chemother. 2006;50(3): 862-7.

138. Tice A. Oritavancin: a new opportunity for outpatient therapy of serious infections. Clin Infect Dis. 2012;54(Suppl 3):S239-43. 
139. Liapikou A, Torres A. Emerging drugs on methicillin-resistant Staphylococcus aureus. Expert Opin Emerg Drugs. 2013; 18(3):291-305.

140. Rubinstein E, Lalani T, Corey GR, et al. Telavancin versus vancomycin for hospital-acquired pneumonia due to gram-positive pathogens. Clin Infect Dis. 2011;52(1):31-40.

141. Lacy MK, Stryjewski ME, Wang W, et al. Telavancin hospitalacquired pneumonia trials: impact of Gram-negative infections and inadequate Gram-negative coverage on clinical efficacy and all-cause mortality. Clin Infect Dis. 2015;61(Suppl 2):S87-93.

142. Corey GR, Kollef MH, Shorr AF, et al. Telavancin for hospitalacquired pneumonia: clinical response and 28-day survival. Antimicrob Agents Chemother. 2014;58(4):2030-7.

143. Torres A, Rubinstein E, Corey GR, et al. Analysis of phase 3 telavancin nosocomial pneumonia data excluding patients with severe renal impairment and acute renal failure. J Antimicrob Chemother. 2014;69(4):1119-26.

144. Bhavnani SM, Passarell JA, Owen JS, et al. Pharmacokineticpharmacodynamic relationships describing the efficacy of oritavancin in patients with Staphylococcus aureus bacteremia. Antimicrob Agents Chemother. 2006;50(3):994-1000.

145. Stryjewski ME, Lentnek A, O'Riordan W, et al. A randomized phase 2 trial of telavancin versus standard therapy in patients with uncomplicated Staphylococcus aureus bacteremia: the ASSURE study. BMC Infect Dis. 2014;14:289.

146. Corey GR, Rubinstein E, Stryjewski ME, et al. Potential role for telavancin in bacteremic infections due to gram-positive pathogens: focus on Staphylococcus aureus. Clin Infect Dis. 2015;60(5):787-96.

147. Joson J, Grover C, Downer C, et al. Successful treatment of methicillin-resistant Staphylococcus aureus mitral valve endocarditis with sequential linezolid and telavancin monotherapy following daptomycin failure. J Antimicrob Chemother. 2011;66(9):2186-8.

148. Marcos LA, Camins BC. Successful treatment of vancomycin-intermediate Staphylococcus aureus pacemaker lead infective endocarditis with telavancin. Antimicrob Agents Chemother. 2010;54(12):5376-8.

149. Kaushal R, Hassoun A. Successful treatment of methicillin-resistant Staphylococcus epidermidis prosthetic joint infection with telavancin. J Antimicrob Chemother. 2012;67(8):2052-3.

150. Twilla JD, Gelfand MS, Cleveland KO, et al. Telavancin for the treatment of methicillin-resistant Staphylococcus aureus osteomyelitis. J Antimicrob Chemother. 2011;66(11):2675-7.

151. Brinkman MB, Fan K, Shiveley RL, et al. Successful treatment of polymicrobial calcaneal osteomyelitis with telavancin, rifampin, and meropenem. Ann Pharmacother. 2012;46(6):e15.

152. Raad I, Darouiche R, Vazquez J, et al. Efficacy and safety of weekly dalbavancin therapy for catheter-related bloodstream infection caused by gram-positive pathogens. Clin Infect Dis. 2005;40(3):374-80.

153. Cho JC, Estrada SJ, Beltran AJ, et al. Treatment of methicillinsensitive Staphylococcus aureus bacteremia secondary to septic phlebitis using dalbavancin. J Clin Pharm Ther. 2015. doi:10. 1111/jept.12306.

154. Barriere S, Genter F, Spencer E, et al. Effects of a new antibacterial, telavancin, on cardiac repolarization (QTc interval duration) in healthy subjects. J Clin Pharmacol. 2004;44(7):689-95.

155. Dunne MW, Zhou M, Darpo B. A thorough QT study with dalbavancin: a novel lipoglycopeptide antibiotic for the treatment of acute bacterial skin and skin-structure infections. Int $\mathbf{J}$ Antimicrob Agents. 2015;45(4):393-8.

156. Stryjewski ME, Graham DR, Wilson SE, et al. Telavancin versus vancomycin for the treatment of complicated skin and skin-structure infections caused by gram-positive organisms. Clin Infect Dis. 2008;46(11):1683-93.
157. Saravolatz LD, Stein GE. Oritavancin: a long-half-life lipoglycopeptide. Clin Infect Dis. 2015;61(4):627-32.

158. Corey GR, Good S, Jiang H, et al. Single-dose oritavancin versus 7-10 days of vancomycin in the treatment of gram-positive acute bacterial skin and skin structure infections: the SOLO II noninferiority study. Clin Infect Dis. 2015;60(2):254-62.

159. Corey GR, Kabler H, Mehra P, et al. Single-dose oritavancin in the treatment of acute bacterial skin infections. N Engl J Med. 2014;370(23):2180-90.

160. Ullman MA, Rotschafer JC. Glycopeptides, lipopeptides, lipoglycopeptides. In: Piscitelli SC, Rodvold KA, Pai MP, editors. Drug interactions in infectious diseases. 3rd ed. New York: Humana Press; 2011. p. 333-54.

161. Tam VH, Ledesma KR, Bowers DR, et al. Kidney injury associated with telavancin dosing regimen in an animal model. Antimicrob Agents Chemother. 2015;59(5):2930-3.

162. Barriere SL, Goldberg MR, Janc JW, et al. Effects of telavancin on coagulation test results. Int J Clin Pract. 2011;65(7):784-9.

163. Wong SL, Goldberg MR, Ballow CH, et al. Effect of telavancin on the pharmacokinetics of the cytochrome P450 3A probe substrate midazolam: a randomized, double-blind, crossover study in healthy subjects. Pharmacotherapy. 2010;30(2):136-43.

164. Wong SL, Sorgel F, Kinzig M, et al. Lack of pharmacokinetic drug interactions following concomitant administration of telavancin with aztreonam or piperacillin/tazobactam in healthy participants. J Clin Pharmacol. 2009;49(7):816-23.

165. Antonanzas F, Lozano C, Torres C. Economic features of antibiotic resistance: the case of methicillin-resistant Staphylococcus aureus. Pharmacoeconomics. 2015;33(4):285-325.

166. Laohavaleeson S, Barriere SL, Nicolau DP, et al. Cost-effectiveness of telavancin versus vancomycin for treatment of complicated skin and skin structure infections. Pharmacotherapy. 2008;28(12):1471-82.

167. Li Y, He Y, Sheng Y, et al. Systematic evaluation of non-inferiority and equivalence randomized trials of anti-infective drugs. Expert Rev Anti Infect Ther. 2013;11(12):1377-89.

168. Henson KE, Levine MT, Wong EA, et al. Glycopeptide antibiotics: evolving resistance, pharmacology and adverse event profile. Expert Rev Anti Infect Ther. 2015;1-14.

169. Infectious Diseases Society of America. White paper: recommendations on the conduct of superiority and organism-specific clinical trials of antibacterial agents for the treatment of infections caused by drug-resistant bacterial pathogens. Clin Infect Dis. 2012;55(8):1031-46.

170. Committee for Human Medicinal Products, EMA. Addendum to the guideline on the evaluation of medicinal products indicated for treatment of bacterial infections. http://www.ema.europa.eu/ema/ pages/includes/document/open_document.jsp?webContentId= WC500153953. Accessed 6 Sep 2015.

171. Kumar A, Mann HJ, Keshtgarpour M, et al. In vitro characterization of oritavancin clearance from human blood by low-flux, high-flux, and continuous renal replacement therapy dialyzers. Int J Artif Organs. 2011;34(11):1067-74.

172. Vilay AM, Shah KH, Churchwell MD, et al. Modeled dalbavancin transmembrane clearance during intermittent and continuous renal replacement therapies. Blood Purif. 2010;30(1): 37-43.

173. Mendes RE, Farrell DJ, Sader HS, et al. Oritavancin microbiologic features and activity results from the surveillance program in the United States. Clin Infect Dis. 2012;54(Suppl 3):S203-13.

174. Jones RN, Sader HS, Flamm RK. Update of dalbavancin spectrum and potency in the USA: report from the SENTRY Antimicrobial Surveillance Program (2011). Diagn Microbiol Infect Dis. 2013;75(3):304-7.

175. McCurdy SP, Jones RN, Mendes RE, et al. In vitro activity of dalbavancin against drug-resistant Staphylococcus aureus 
isolates from a global surveillance program. Antimicrob Agents Chemother. 2015;59(8):5007-9.

176. Leighton A, Gottlieb AB, Dorr MB, et al. Tolerability, pharmacokinetics, and serum bactericidal activity of intravenous dalbavancin in healthy volunteers. Antimicrob Agents Chemother. 2004;48(3):940-5.

177. Kiem S, Schentag JJ. Interpretation of epithelial lining fluid concentrations of antibiotics against methicillin resistant Staphylococcus aureus. Infect Chemother. 2014;46(4):219-25.

178. Gotfried MH, Shaw JP, Benton BM, et al. Intrapulmonary distribution of intravenous telavancin in healthy subjects and effect of pulmonary surfactant on in vitro activities of telavancin and other antibiotics. Antimicrob Agents Chemother. 2008;52(1): 92-7.

179. Lodise TPJ, Gotfried M, Barriere S, et al. Telavancin penetration into human epithelial lining fluid determined by population pharmacokinetic modeling and Monte Carlo simulation. Antimicrob Agents Chemother. 2008;52(7):2300-4.

180. Stryjewski ME, O'Riordan WD, Lau WK, et al. Telavancin versus standard therapy for treatment of complicated skin and soft-tissue infections due to gram-positive bacteria. Clin Infect Dis. 2005;40(11):1601-7.

181. Jauregui LE, Babazadeh S, Seltzer E, et al. Randomized, doubleblind comparison of once-weekly dalbavancin versus twicedaily linezolid therapy for the treatment of complicated skin and skin structure infections. Clin Infect Dis. 2005;41(10):1407-15.

182. Boucher HW, Talbot GH, Dunne MW. Dalbavancin or oritavancin for skin infections. N Engl J Med. 2014;371(12):1161-2.

183. Drugs for MRSA skin and soft-tissue infections. JAMA. 2014;312(15):1583-4. 